\title{
Stratigraphy, petrography and tectonics of the manganese-bearing Buritirama Formation, Northern Carajás Domain, Amazon Craton
}

\author{
Silas Santos Salgado ${ }^{1,2 *}$ (D), Fabrício de Andrade Caxito ${ }^{1,2}$ (D), Glaucia Nascimento Queiroga ${ }^{3}$ (D), \\ Marco Paulo de Castro 3 iD
}

\begin{abstract}
The Buritirama Formation (BF) occurs at the extreme north of the Carajás Province, close to the contact with the Bacajá domain, in the southeastern portion of the Amazon Craton (Brazil). The BF consists of a $40 \mathrm{~km}$ long, ca. $3 \mathrm{~km}$ wide NW-SE trending structure arranged in four imbricated thrusts that individualize three main stratigraphic units. The lower unit is composed of orthoquartzite followed by carbonate-silicate rocks. The intermediate unit hosts a supergene manganese ore deposit formed by weathering of kutnohorite-rich marble. Quartzite/mica-quartz schist followed by carbonate-silicate rocks make up the upper unit. The local basement is constituted by orthogneiss-migmatite (Xingu Complex) and the Buritirama metagranite. Mineral chemistry data and metamorphic textures record high consumption of carbonate and quartz to produce clinopyroxenes. The structural assemblage of the $\mathrm{BF}$ records mass transport from $\mathrm{NE}$ to $\mathrm{SW}$ and the following deformational phases: D1 (compressional ductile), D2 (compressional brittle) and D3 (extensional brittle). The BF is interpreted as part of a platformal depositional system positioned at the border of the Carajás domain, which was probably inverted, deformed and metamorphosed during the Transamazonian event (ca. $2.1 \mathrm{Ga}$ ), in a deformation belt related to the amalgamation between the Carajás and Bacajá domains.
\end{abstract}

KEYWORDS: Manganese deposit; Carajás; Bacajá; carbonate-silicate rocks; paleoproterozoic.

\section{INTRODUCTION}

The Carajás province (3000-2500 Ma) is the oldest part of the Amazon craton and it is located in the southeastern Pará state, north of Brazil (Santos et al. 2000, Santos 2003). It comprises one of the largest mineral provinces of the world (Carajás Mineral Province), hosting world-class deposits of iron, copper, and gold (DOCEGEO 1988, Grainger et al. 2008). Based on geochronological data, the province was subdivided into the essentially Neoarchean Carajás domain (northern portion) and the Mesoarchean Rio Maria domain (southern portion; Gibbs et al. 1986, Machado et al. 1991, Santos 2003, Vasquez \& Rosa-Costa 2008, Dall'Agnol et al. 2013).

\footnotetext{
Supplementary material

Supplementary data associated with this article can be found in the online version: Supplementary Table A1, Supplementary Table A2, Supplementary Table A3 , Supplementary Table A4, Supplementary Table A5, Supplementary Table A6 and Supplementary Table A7.

${ }^{1}$ Centro de Pesquisas Manoel Teixeira da Costa - Belo Horizonte (MG), Brazil. E-mails: silasalgado83@gmail.com, caxito@ufmg.br

${ }^{2}$ Programa de Pós-Graduação em Geologia, Instituto de Geociências, Universidade Federal de Minas Gerais - Belo Horizonte (MG), Brazil.

${ }^{3}$ Departamento de Geologia, Escola de Minas, Universidade Federal de Ouro Preto - Ouro Preto (MG), Brazil. E-mail: glauciaqueiroga@yahoo.com.br

${ }^{*}$ Corresponding author
}

(C) 2019 The autors. This is an open access article distributed under the terms of the Creative Commons license.
The Carajás domain is bordered to the west by Iriri-Xingu domain (1992-1860 Ma; Semblano et al. 2016), to the east by the Neoproterozoic/Cambrian (Brasiliano) Araguaia Belt (850-500 Ma; Herz et al. 1989, Moura \& Gaudette 1993, Alvarenga et al. 2000), and to the north by the Bacajá domain (Transamazonas province - 2600-2070 Ma; Vasquez 2006, Besser 2012). The limits among these geotectonic units are still poorly understood, but especially the northern boundary between the Carajás and Bacajá domains was subject to different interpretations in the last years (Ricci et al. 2003, Faraco et al. 2005, Vasquez \& Rosa-Costa 2008, Costa et al. 2016).

The Buritirama Formation, at the homonymous ridge, consist of a ca. $40 \mathrm{~km}$ long and ca. $3 \mathrm{~km}$ wide NW-SE trending structure that plays a key role in this context, since it stands right in the border zone between the Carajás and Bacajá domains and was variably interpreted as a member of both terrains (Vasquez \& Rosa-Costa 2008, Costa et al. 2016, Tavares 2015). This formation is also noteworthy because it hosts supergene Mn deposits with resources estimated at 18.6 Mt (Andrade et al. 1986) and mined by Buritirama Company since 2000.

Considering the lack of information about the Buritirama Formation, the aim of this paper was to provide the first systematic structural and stratigraphic framework of this unit coupled with new petrographic and mineral chemistry data. We presented preliminary insights in an attempt to elucidate the meaning of the Buritirama Formation in the amalgamation between the Carajás and Bacajá blocks. 


\section{GEOLOGICAL SETTING}

The Amazon Craton (Almeida et al. 1976, Almeida et al. 1981) is the largest cratonic unit of the South American platform, with area of $4.500 .000 \mathrm{~km}^{2}$ spreading through Brazil, French Guyana, Guyana, Suriname, Venezuela, Colombia and Bolivia. It is formed by Archean nuclei composed of greenstone belts and gneiss-migmatitic terrains (TTG) surrounded by Proterozoic orogenic belts (Almeida et al. 2000, Brito Neves \& Cordani 1991, Cordani et al.2000). Based on geochronological, geophysical, structural, geochemical and isotopic data, several authors have proposed different compartmentalization models for the Amazon Craton over the years (e.g., Hasui \& Almeida 1985, Costa \& Hasui 1997, Tassinari \& Macambira 1999, 2004, Santos et al. 2000, Santos 2003, Vasquez \& Rosa-Costa 2008). Here, we assume the latest compilation model provided by Vasquez and Rosa-Costa (2008) in the geological map of Pará state (Fig. 1).

Following works developed by Santos (2003) and Vasquez and Rosa-Costa (2008) the Amazon Craton is individualized in seven main tectonic provinces:

- Carajás (3.0-2.5 Ga; Carajás and Rio Maria domains);

- Transamazonas (2.2-1.9 Ga);

- Tapajós-Parima (2.0-1.8 Ga);

- Amazônia Central (1.9-1.8 Ga);

- Rondônia-Juruena (1.8-1.5 Ga);

- Rio Negro (1.8-1.5 Ga);

- Sunsás (1.4-1.0 Ga).

In this scenario, the northern segment of the Carajás domain is composed of three main geochronological units (Fig. 2; Vasquez \& Rosa-Costa 2008, Costa et al. 2016):

- Mesoarchean Unit: it is represented by the tonalite-trondhjemite-granodiorite (TTG) gneiss-migmatitic sequence of the Xingu Complex (Silva et al. 1974, Cordani et al. 1984), dated at 3.0-2.85 Ga (Machado et al. 1991, Pidgeon et al. 2000, Delinardo 2014). In its southern border, it is thrust upon metavolcano-sedimentary groups related to Itacaiúnas supergroup through the Cinzento shear zone;
- Neoarchean Unit: in the eastern part of the Carajás domain, it is represented by the Rio Novo greenstone belt (Araújo \& Maia 1991), genetically related to mafic-ultramafic rocks comprising the Luanga Complex (Suita 1988, Ferreira Filho et al. 2007), dated at $2763 \pm 6 \mathrm{Ma}$ (U-Pb; Machado et al. 1991). In the central part of the Carajás domain, the Neoarchean unit consists of the A-type calc-alkaline Igarapé-Gelado metagranite, dated at $2731 \pm 26 \mathrm{Ma}(\mathrm{Pb}-\mathrm{Pb}$; Barbosa 2004) and limited by the Carajás lineament to the south. The Itacaiúnas supergroup (DOCEGEO 1988) represents the major Neoarchean unit and is formed by the correlate metavolcano-sedimentary groups Igarapé Salobo, Igarapé Bahia, Igarapé Pojuca, Rio Novo and Grão-Pará (Vasquez \& Rosa-Costa 2008). The Grão-Pará group is represented by basalt-gabbro and andesite (Parauapebas Formation; Meireles et al. 1984, Araújo \& Maia 1991) and the giant iron deposits comprising the Carajás Formation (Beisiegel et al. 1973, Macambira 2003). These rocks were dated around 2.77-2.50 Ga (Wirth et al. 1986, Macambira et al. 1996, Trendall et al. 1998) and were probably deposited in a continental rift setting (Gibbs et al. 1986, DOCEGEO 1988, Macambira 2003, Martins 2017). The Igarapé Salobo, Igarapé Bahia, Igarapé Pojuca and Rio Novo groups are metavolcano-sedimentary units (DOCEGEO 1988) that are distinguished by distinct structural pattern and metamorphic grade (Winter 1994, Siqueira 1996, Pinheiro 1997), but being temporally related (ca. 2.70 Ga; Machado et al. 1991, Tallarico et al.2005). The Buritirama ridge (Anderson et al. 1974, Peters et al. 1977, Bello 1978) has been inserted in different lithostratigraphic settings, being linked to the Buritirama group (Itacaiúnas Supergroup - Carajás Domain; DOCEGEO 1988) and the Buritirama Formation (Vila União group - Bacajá Domain; Vasquez \& Rosa-Costa 2008). Both interpretation have connected the Buritirama ridge with distinct tectonic provinces and stratigraphic hierarchy, despite none of these works are supported by specifically studies on the Buritirama unit. Considering that, based on the above-mentioned authors and

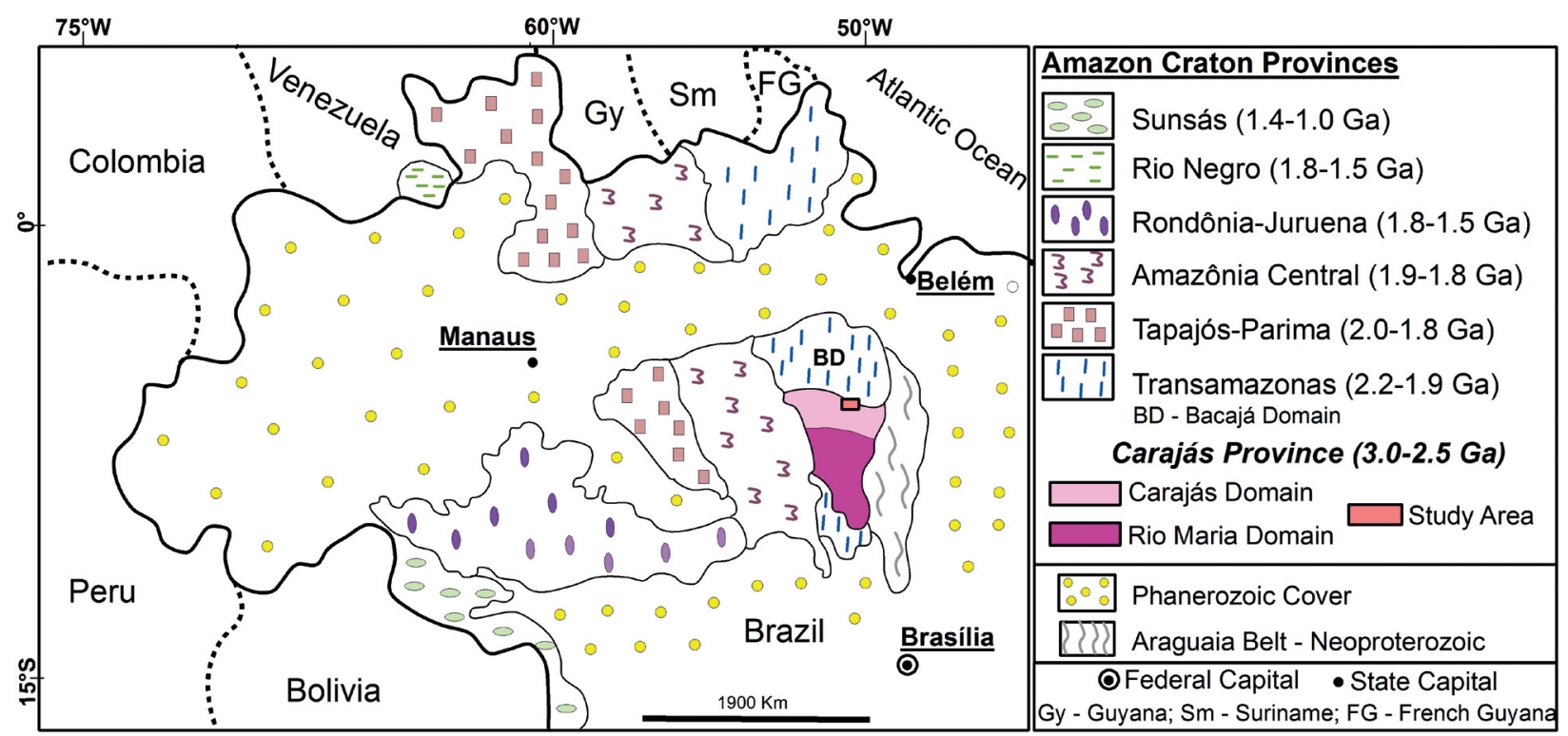

Figure 1. Tectonic provinces of the Amazon Craton (Vasquez \& Rosa-Costa 2008) showing location of the study area at the border between the Carajás (Archean) and Bacajá (Paleoproterozoic) domains. 
the new geological data presented in this paper, we assumed the Buritirama ridge as part of the Buritirama Formation (Vila União group), but belonging to the Itacaiúnas supergroup (Carajás domain). The Buritirama group also includes the poorly understood Tapirapé Formation (Oliveira 1994) that comprehends metabasalts and talc-schist (Fig. 2). The Buritirama Formation (BF) is located at the northern part of Carajás domain and hosts important manganese mineralization associated with carbonate-silicate rocks and marbles. It was interpreted as deposited in a shallow platform basin and later metamorphosed during the Transamazonic event (ca. 2.0-2.2 Ga) at amphibolite conditions (ca. $550^{\circ} \mathrm{C}$; Peters et al. 1977). Despite no geochronological data are available for this unit, the Neoarchean age assumed comes from previously interpretations (e.g., DOCEGEO 1988, Vasquez \& Rosa-Costa 2008, Tavares 2015);

- Paleoproterozoic Unit: it is represented by clastic continental sedimentary rocks of the Caninana Formation (maximum age 2.1 Ga - U-Pb; Pereira 2009). The Paredão group (Oliveira 1994) and the Águas Claras Formation (Araújo et al. 1988) have been also assumed to be of Paleoproterozoic age (Tavares et al. 2018). Anorogenic sienogranites and monzogranites (Serra dos Carajás Suite) dated at $1.88 \mathrm{Ga}$ also belong to this unit (Machado et al. 1991, Dall'Agnol et al. 2005).

\section{MATERIALS AND METHODS}

Fieldwork was conducted in the Buritirama ridge, in order to constrain its lithology, stratigraphy and structural geology. To build up the Buritirama stratigraphy, 21 borehole cores (supplied by Buritirama Mineração) combined with field data were employed. Unweathered samples were selected for the preparation of 55 polished thin section that were used in the petrographic characterization and mineral chemistry analyses.

Metacarbonate and associated rocks were classified according to the scheme proposed by Rosen et al. (2007). Non-carbonate rocks were informally called silicate rocks or referred to their respective protoliths (e.g., quartzite, metagranite).

Electron microprobe analysis (EMPA) were performed in a JEOL JXA-8230 superprobe, equipped with five wavelength dispersive spectrometers (WDS), at the Microscopy and Microanalysis Laboratory (LMic) of the Department of Geology, Universidade Federal de Ouro Preto, Brazil. Six different crystals were used:

- thallium acid phthalate on $\mathrm{H}$ type spectrometer (TAPH in WDS 1);

- thallium acid phthalate (TAP in WDS 2);

- lithium floride on H type spectrometer (LIFH in WDS 3);

- pentaerythritol on H type spectrometer (PETH in WDS 3);

- pentaerythritol (PETL in WDS 5);

- lithium fluoride (LIFL in WDS 5).

The JEOL EMPA software version 3.0.1.16 package was used to perform the calibration, overlap correction and quantification. Operating conditions were $15 \mathrm{kV}$ accelerating voltage, $20 \mathrm{nA}$ beam current and $5 \mu \mathrm{m}$ beam diameter. The work distance on EMPA is fixed at $11 \mathrm{~mm}$ with no variation during the analysis. The following standards were used for calibration: anorthoclase $(\mathrm{Na}), \mathrm{CaF}_{2}(\mathrm{~F})$, quartz $(\mathrm{Si})$, corundum $(\mathrm{Al})$, olivine $(\mathrm{Mg})$, magnetite $(\mathrm{Fe})$, scapolite $(\mathrm{Cl}), \mathrm{BaSO}_{4}(\mathrm{Ba})$, fluor-apatite $(\mathrm{P}, \mathrm{Ca})$, strontianite $(\mathrm{Sr})$, ilmenite $(\mathrm{Ti})$, chromite

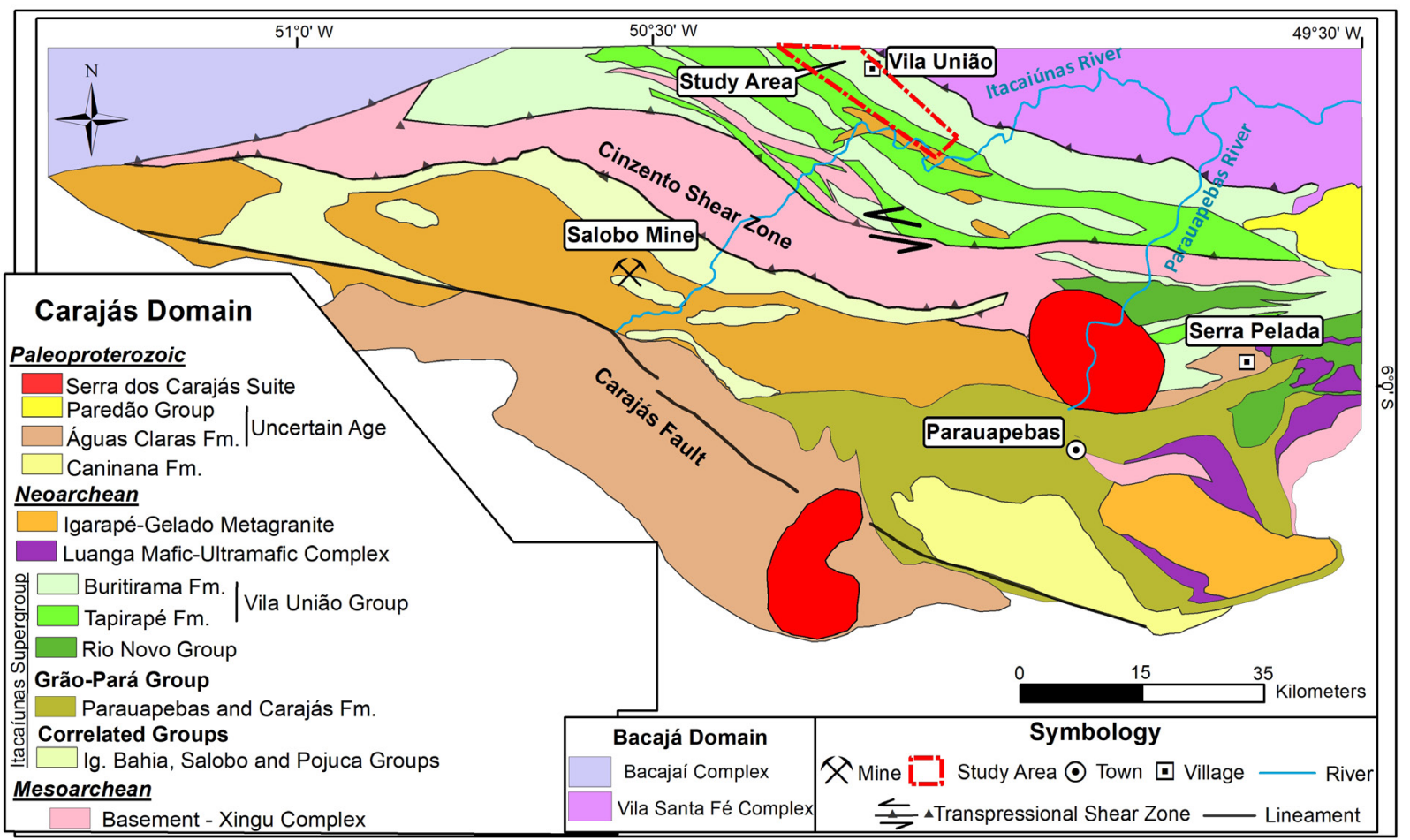

Figure 2. Geological map of the northern Carajás Domain (modified from Costa et al. 2016) presenting the study area (red polygon) near Vila União. 
(Cr), microcline (K) and $\mathrm{MnO}_{2}(\mathrm{Mn})$. Counting time for $\mathrm{Ba}$, $\mathrm{Sr}$ and $\mathrm{P}$ were set at $30 \mathrm{~s}$ at peak and $15 \mathrm{~s}$ at background, while for $\mathrm{Na}, \mathrm{F}, \mathrm{Si}, \mathrm{Al}, \mathrm{Mg}, \mathrm{Fe}, \mathrm{Cl}, \mathrm{Cr}, \mathrm{Ti}, \mathrm{Ca}, \mathrm{Mn}$ and $\mathrm{K}$ were set at $10 \mathrm{~s}$ at peak and $5 \mathrm{~s}$ at background. The major spectral interferences were corrected during the standard analysis and during the quantification. L $\alpha \mathrm{X}$-ray was used for $\mathrm{Ba}$ and $\mathrm{Sr}$, while $\mathrm{K} \alpha$ $\mathrm{X}$-ray was used for the other elements. The standard deviation for each element was: $\mathrm{Na}(1 \%), \mathrm{F}(1.05 \%), \mathrm{Si}(0.29 \%), \mathrm{Al}$ (0.45\%), $\mathrm{Mg}$ (0.46\%), Fe (0.4\%), Cl (0.97\%), Ba (0.29\%), P (0.61\%), Sr (0.68\%), Ti (0.29\%), Cr (0.54\%), Ca (0.25\%), $\mathrm{K}(0.49 \%)$ and $\mathrm{Mn}(0.43 \%)$.

\section{RESULTS}

\section{Geology of the Buritirama Formation}

The BF outcrops in the homonymous ridge along a 40-km-long NW-SE structure and shows variable thickness (maximum around $900 \mathrm{~m}$ ). It dips predominantly at $30^{\circ}$ to northeast. The Itacaiúnas River defines its southeast border where the ridge ends in an anticlinal structure with the Buritirama metagranite in its core. To the southwest, it is thrust over the Xingu Complex orthogneisses (Carajás domain), and to the northeast, a quartz, iron-rich shear zone marks the contact between the $\mathrm{BF}$ and the probably Bacaja domain (Figs. 3A and 3B).

\section{Stratigraphy}

The stratigraphy of the BF type section is marked by four imbricated thrusts that individualize three main metamorphic units (Figs. 3B and 4): lower unit (LU); intermediate unit (IU), and upper unit (UU). Based on fieldwork combined with borehole logging, each unit was separated according to the dominant lithotypes: silicate rocks, carbonate-silicate rocks, calc-silicate rocks and impure marbles. It is important to emphasize that these lithotypes are strongly intercalated throughout the sequence, thus we will always refer to the predominant lithotype.

- LU: it is represented by a thick (approximately $200 \mathrm{~m}$ ) rock package made up of orthoquartzite and minor mica-quartz

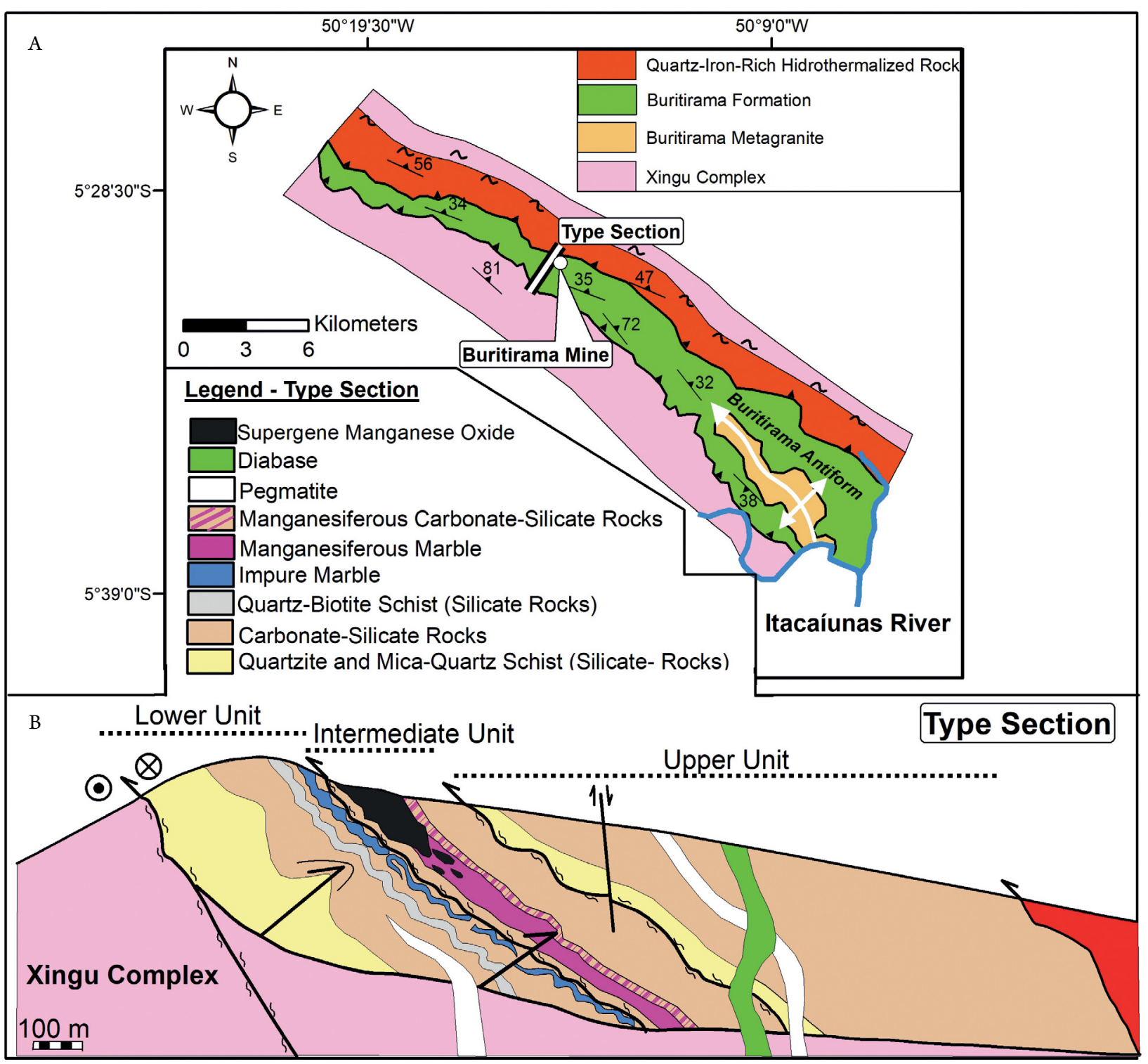

Figure 3. (A) Geological map of the Buritirama ridge (for location see Fig. 2); (B) type section of the Buritirama Formation showing the individualized lower, intermediate and upper units. 
schist that are followed mainly by carbonate-silicate rocks $(\mathrm{Mc} \pm \mathrm{Phl} \pm \mathrm{Cb}+$ Di paragneiss; Fig. $5 \mathrm{~A}$; mineral abbreviations according to Whitney \& Evans 2010). Near the uppermost contact, layers of silicate rocks (Alm \pm Cum $\pm \mathrm{Pl}+\mathrm{Qz}+\mathrm{Bt}$ schist $)$ and impure marble $(\mathrm{Di}+\mathrm{Phl}+\mathrm{Cb}$ marble) occur (Figs. 5B and 5C). A strike-slip dextral shear zone set in orthogneiss-migmatite of the Xingu Complex bounds the basal contact and, in this area, the BF records its highest dipping (approximately $75^{\circ} \mathrm{NE}$; Fig. 5D);

- IU: the supergene manganese ore deposit is hosted in this unit (up to $70 \mathrm{~m}$ thick) and is formed by weathering of kutnohorite-rich marble (Figs. 5E and 5F). Manganesiferous marble (ca. 20-m thick) grades to Mn-rich carbonate-silicate rocks $(\mathrm{Mn}-\mathrm{Cal} \pm \mathrm{Mn}-\mathrm{Di}+\mathrm{Phl}$ paragneiss/schist $)$ and silicate rocks $(\mathrm{Qz}+\mathrm{Pl}+\mathrm{Bt}$ schist $)$. Mylonitic textures present in the basal contact define a ductile thrust upon the LU;

- UU: it is very similar to the LU. At the base, sheared quartzite (minor) and mica-quartz schist record a ductile thrusting upon IU. A thick layer of carbonate-silicate rocks intercalated with minor lenses of silicate rocks and impure

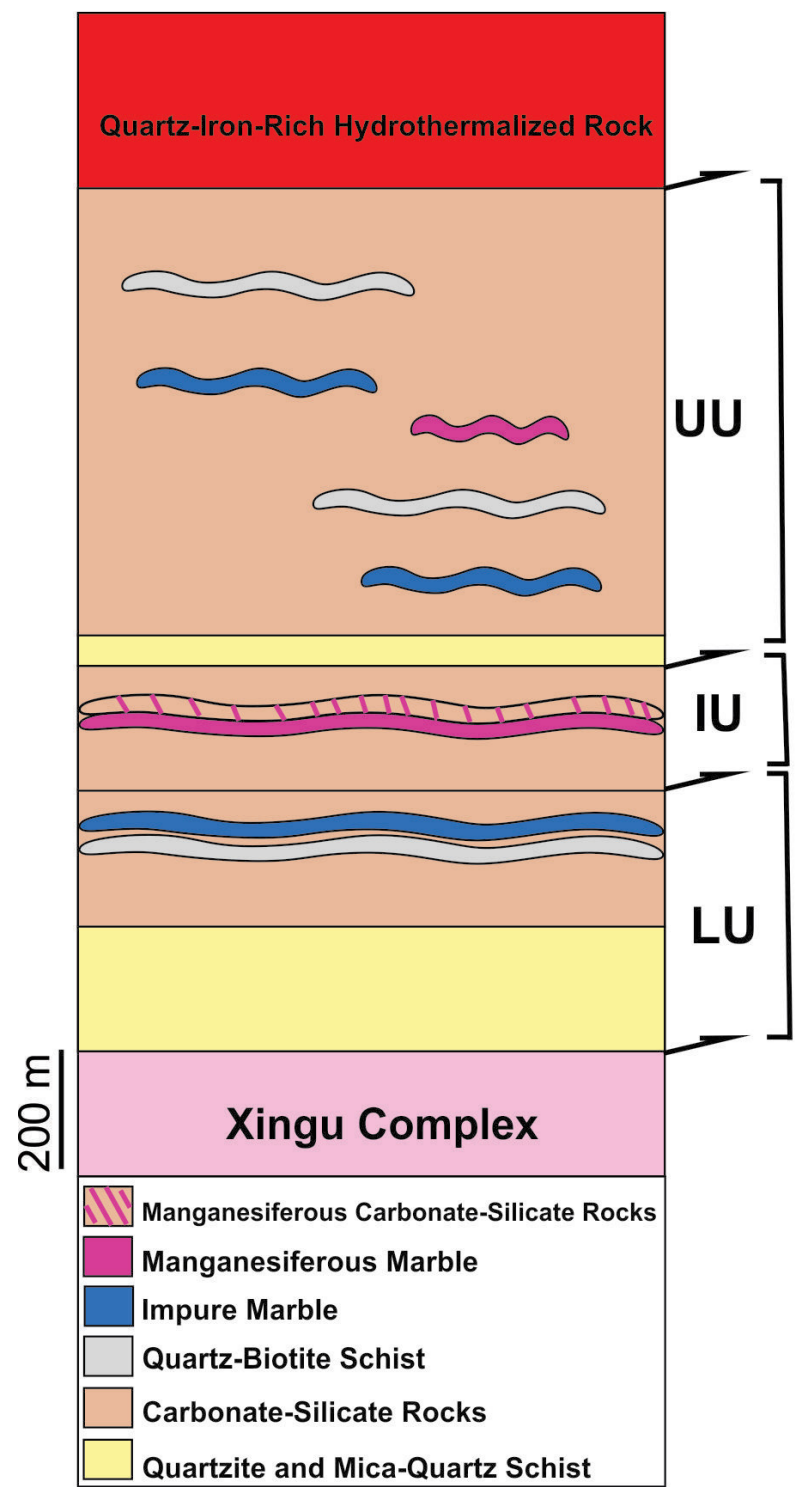

Figure 4. Tectonic-stratigraphic column of the Buritirama Formation in its type-section. marbles (occasionally Mn-rich) comes next. The uppermost contact is defined by hydrothermalized rocks rich in quartz, iron oxide (Fig. 5G), and related to a compressional shear zone that has been impressed on the Xingu Complex.

A deformed alkaline porphyritic granite (Buritirama metagranite) composed essentially of perthitic-Mc, Qtz, Pl, Bt and Mag was recognized near the Itacaiúnas River and comprises the local basement of the BF (Fig. 5H). Undeformed sills and dikes of pegmatite and later diabase cut the ridge (Fig. 5I).

\section{Petrography}

Based on visually-estimated modal mineralogy, the metamorphic rocks of the $\mathrm{BF}$ were classified as impure marble, carbonate-silicate rocks, calc-silicate rocks and silicate rocks. Manganesiferous varieties were also recognized. These groups of rocks record two main penetrative fabrics (metamorphic banding and schistosity), depending on the greater or lesser amount of carbonates/pyroxenes in relation to phyllosilicates (e.g., phlogopite-biotite). The banding occurs preferentially in carbonate-silicate rocks, whereas silicate rocks show greater contents of phyllosilicates and, therefore, a conspicuous schistosity.

Carbonate-silicate rocks are the main lithotype of the BF and consist of dark and greenish rocks with seriate, nematoblastic, lepidoblastic and/or granoblastic fabrics. It is composed of diopside (40-30\%vol), calcite (40-15\%vol), phlogopite (35-15\%vol) and microcline (<15\%vol). Quartz, plagioclase and spessartine (syn and post-tectonic) are subordinate. The rocks commonly show a prominent metamorphic banding $(<1.5 \mathrm{~cm}$; Fig. 6A) defined by intercalation of diopside and phlogopite-carbonate layers.

Diopside occurs as large poikiloblastic and porphyroblast (less common) crystals up to $1.5 \mathrm{~cm}$, containing inclusions of all above-mentioned minerals. Calcite/dolomite is present as subhedral medium-grained crystals with straight boundaries and triple junctions. Phlogopite occurs as anhedral medium-grained tabular crystals. Microcline hardly shows its typical twinning, exhibits expressive modal variation and usually occurs as inclusions in diopside (Fig. 6B). Carbonate-silicate rocks change into a manganesiferous variety (MCBS) by the introduction of manganese in the structure of minerals: Mn-diopside, Mn-calcite/kutnohorite and Mn-phlogopite.

Calc-silicate rocks is a class of rocks that shares many similarities with carbonate-silicate rocks, like fabrics, colour and mineralogy. Nevertheless, they differ by the low abundance of carbonates and phlogopite.

Impure marbles are present mainly in the lower unit and are formed essentially by coarse-grained crystals (up to $2.5 \mathrm{~mm}$ ) of calcite and dolomite (> 50\%vol) arranged in a polygonal fabric (granoblastic; Fig.6C). Tabular, fine to medium-grained crystals of phlogopite are oriented and locally exhibit deformational structures (e.g., kink bands). Poikiloblastic diopside crystals bearing inclusions of carbonates, phlogopite and minor quartz and microcline are present. Secondary tremolite commonly replaces diopside.

Apatite, titanite, magnetite and sulphides are the main accessory minerals in impure marbles and carbonate-silicate rocks.

Manganesiferous marbles are restricted to the IU and is composed of kutnohorite/Mn-calcite (>50\%vol), spessartine 
(30-10\%vol), kanoite ( 15\%vol), Mn-phlogopite (<15\%vol) and rhodonite (<10\%vol; Fig. 6D). Medium-grained carbonates occur with typical polygonal fabric. Euhedral, fine-grained $(\sim 0.05 \mathrm{~mm})$ spessartine crystals are distributed throughout the rock. Kanoite (Kan; rare Mn-clinopyroxene) occurs as medium to coarse-grained poikiloblastic crystals and bears kutnohorite inclusions. Oriented subhedral crystals of carbonate-bearing rhodonite are also present. Mn-phlogopite exhibit its typical tabular habit. It is important to note that all cited minerals were recognized by microprobe analyses. Quartz, microcline, apatite, sulphides and barite are present as minor minerals. Manganesiferous marbles represent the proto-ore, later overprinted by supergene processes giving rise to Mn-oxides (Fig. 6E).

Silicate rocks are a class that is represented by three main lithologies (orthoquartzite, biotite schist and mica-quartz schist). Orthoquartzite and biotite schist occur mainly in the LU, while mica-quartz schist was also recognized in the UU. Orthoquartzite is formed by anhedral, medium to coarse-grained crystals of quartz, characterized by conspicuous dynamic recrystallization fabric (subgrains and interlobate grain boundaries). Minor muscovite and magnetite are present. Biotite schist (Fig. 6F) shows a prominent lepidoblastic fabric and is composed essentially of biotite (> $50 \% \mathrm{vol})$, quartz $(30-10 \% \mathrm{vol})$, plagioclase $(30-5$ $\% \mathrm{vol})$, cummingtonite (<10\%vol), microcline (<10\%vol) and almandine $(<5 \% \mathrm{vol})$. Ilmenite, zircon, titanite and sulphides occur as accessory minerals.
Mylonitic fabrics as pressure shadows and $\mathrm{S}-\mathrm{C}$ foliations are present close to the main shear zones, and remarkable post-tectonic features, such as annealing and overgrown minerals, are ubiquitous in all studied units. Evidence of retrometamorphic processes like uralitization, chloritization, sericitization and saussuritization is also observed.

\section{Mineral chemistry}

Chemical compositions were determined for carbonate, pyroxene, garnet, feldspar, pyroxenoid, amphibole and mica that occur in the main BF lithotypes (see Suppl. Tables A1-A7):

- Carbonate: calcite (Fig. 7A) occurs mainly in carbonate-silicate rocks and impure marbles (normally surrounding phlogopite crystals). Kutnohorite and Mn-calcite are present in different samples of manganesiferous marbles and record a Mn-enrichment trend. Dolomite is restricted to impure marbles, however, high grades of $\mathrm{Mg}$ are also reported in kutnohorite $\left(\mathrm{MgCO}_{3}\right.$ up to $\left.20 \mathrm{Mol} \%\right)$;

- Pyroxene: diopside, Mn-diopside and kanoite are present in carbonate-silicate rocks, calc-silicate rocks and manganesiferous marbles, respectively. These minerals show a clear Mn-enrichment trend, from diopside to kanoite (Fig. 7B);

- Garnet: it is mainly represented by the end-members spessartine and almandine (Fig. 7C). Spessartine occurs in manganesiferous marbles and shows mole fraction of pyrope and grossular below $10 \%$. In calc-silicate rocks,
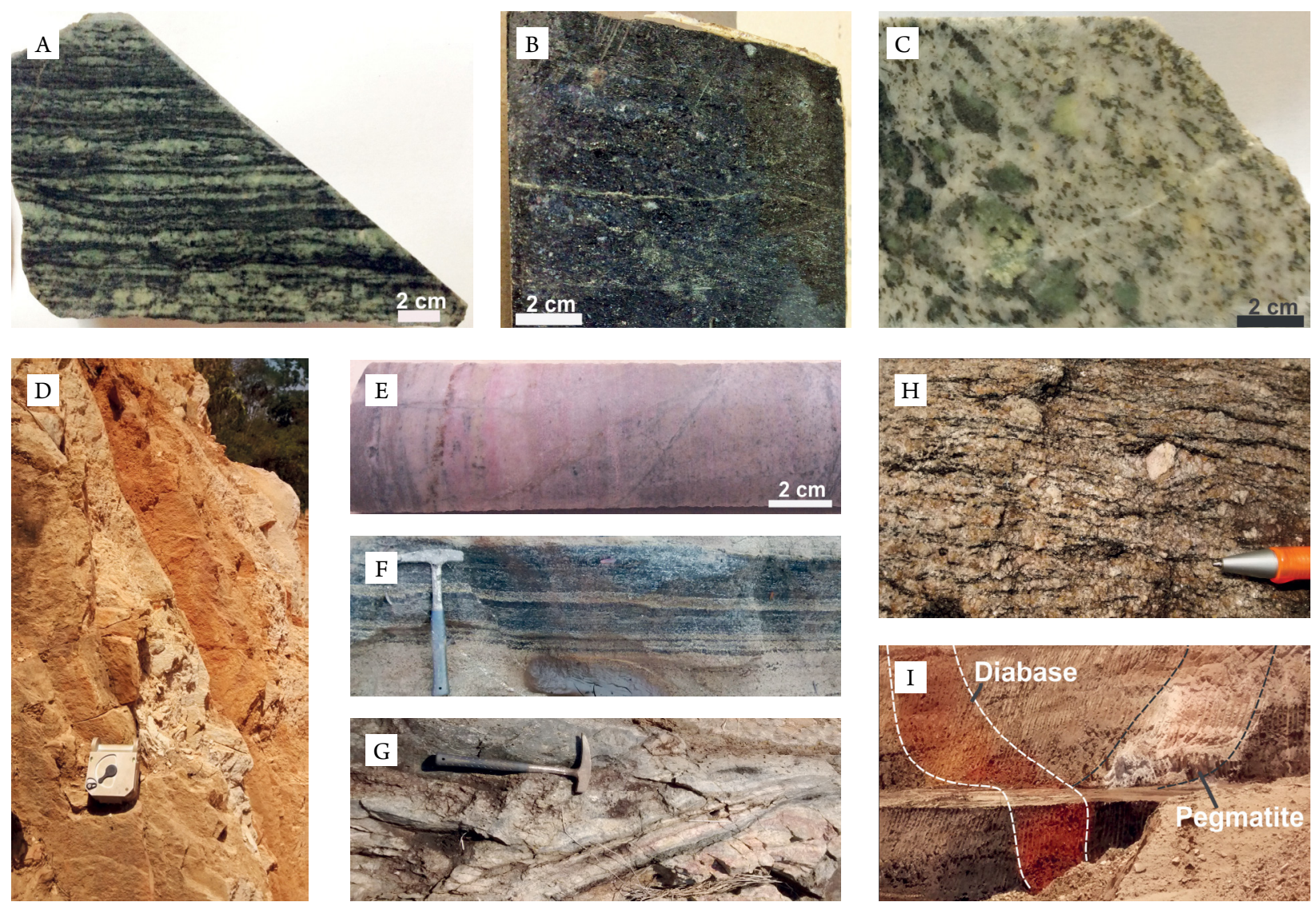

Figure 5. General aspects of Buritirama Formation lithotypes. (A) $\mathrm{Mc} \pm \mathrm{Cb} \pm \mathrm{Phl}+\mathrm{Di}$ paragneiss (carbonate-silicate rock); (B) $\mathrm{Alm} \pm \mathrm{Cum} \pm$ $\mathrm{Pl}+\mathrm{Qz}+\mathrm{Bt}$ schist (silicate rock); (C) $\mathrm{Tr}+\mathrm{Phl}+\mathrm{Cb}$ marble (impure marble); (D) steeply dipping quartzite present at the base of Buritirama Formation; (E) kutnohorite-marble (manganesiferous marble); (F) layers of Mn-oxide (kutnohorite-marble protolith) and clay minerals (carbonate-silicate rock protolith) intercalated; $(\mathrm{G})$ hydrothermalized rock rich in quartz and magnetite (Xingu Complex); (H) sheared porphyritic granite (Buritirama Metagranite); (I) a diabase dike cross-cutting a pegmatite dike, both intensely weathered. 
the grossular mole fraction in spessartine reaches up to $30 \%$. Almandine is restricted to silicate rocks and contains up to $45 \mathrm{Mol} \%$ of grossular and pyrope, the former being dominant;

- Feldspar: microcline is the main feldspar present in carbonate-silicate rocks and impure marbles. Ba-rich microcline (up to $5 \mathrm{wt} \%$ of $\mathrm{BaO}$ ) also occurs in these rocks. Andesine with intergrowth of labradorite (anorthite mole fraction up to $52 \%$ ) and anorthoclase (K-Fds mole fraction up to 24\%) was recognized in the silicate rocks (Fig. 7D);
- Pyroxenoid: it is represented by rhodonite crystals present exclusively in manganesiferous marbles (Fig. 7E). Rhodonite is characterized by high $\mathrm{MgSiO}_{3}$ contents (up to $30 \mathrm{Mol} \%$ );

- Amphibole: tremolite, cummingtonite andMn-cummingtonite (Fig. 7F) are present in impure marbles, silicate rocks and calc-silicate rocks, respectively;

- Micas: phlogopite occurs in carbonate-silicate rocks and manganesiferous marbles, while Mn-phlogopite is present in the varieties of these rocks. Biotite is restricted to silicate rocks (Fig. 8).
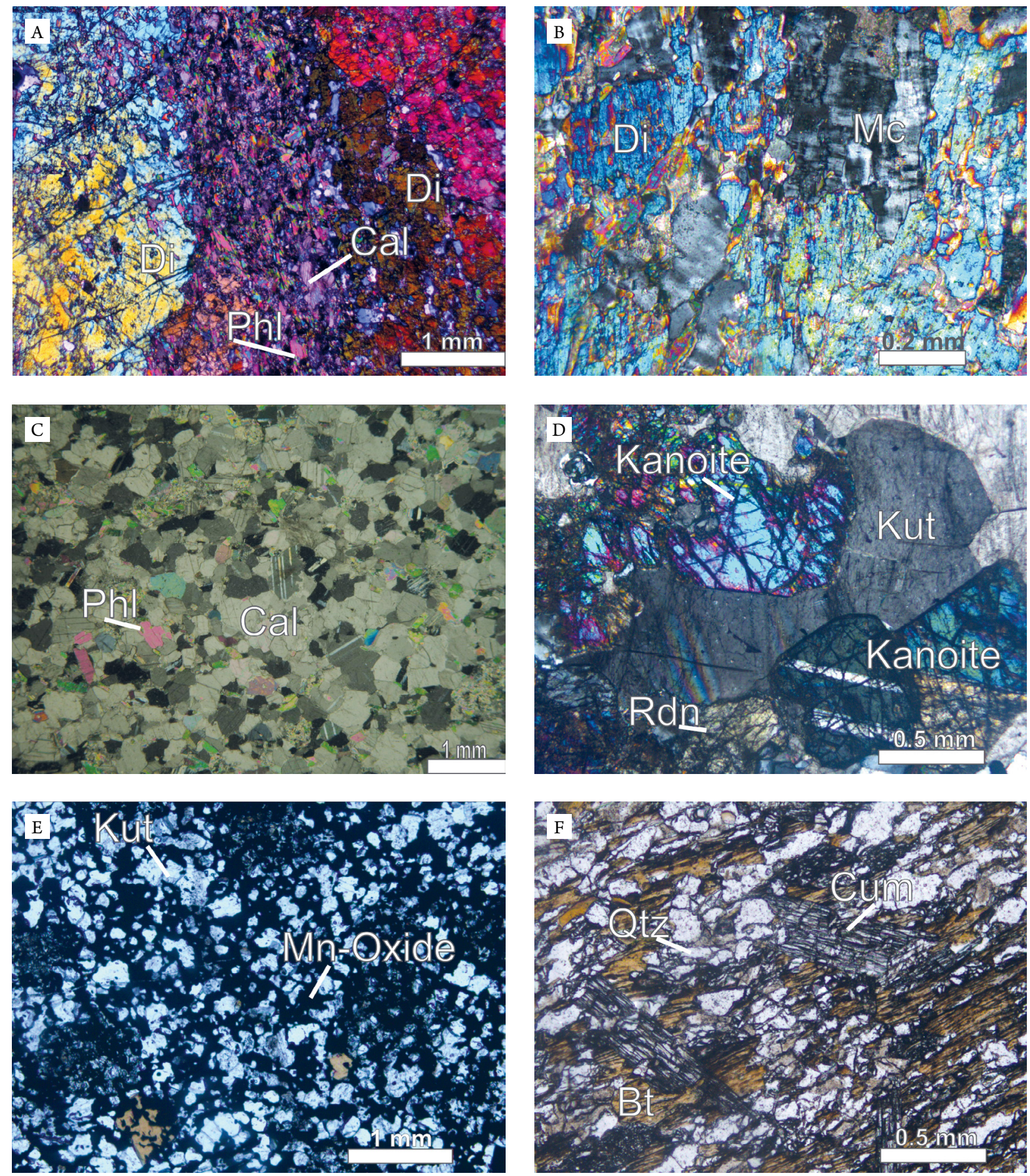

Figure 6. Petrographic aspects of rocks from the Buritirama Formation under the microscope (crossed polarizers, except F): (A) banded Mc-Phl-Cal-Di paragneiss; (B) poikiloblast of diopside bearing microcline inclusion (carbonate-silicate rocks); (C) impure marble showing typical granoblastic fabric; (D) kanoite, kutnohorite and rhodonite present in manganesiferous marble; (E) manganese oxides formed by kutnohorite weathering; (F) cummingtonite-quartz-biotite schist. 


\section{Structural geology}

The structural framework of the Buritirama ridge is the result of polyphasic deformation divided in three main phases:

- Phase D1: it starts with earlier formed rootless intrafolial folds (F1) and a penetrative axial-plane foliation (S1) parallel to metamorphic banding (Bn; Fig. 9A). S1 is folded into isoclinal folds (F2; Fig. 9B) verging to SW with hinge dipping to NW and NE. A second penetrative axial-plane foliation (S2; Fig. 9C) is recognized in the F2 hinge zone. S2 is usually parallel to $S 1 / / \mathrm{Bn}$ and dips preferentially to NE with modal maximum at $025 / 30$ (Fig. 9D). Down-dip and slightly oblique mineral stretching

A

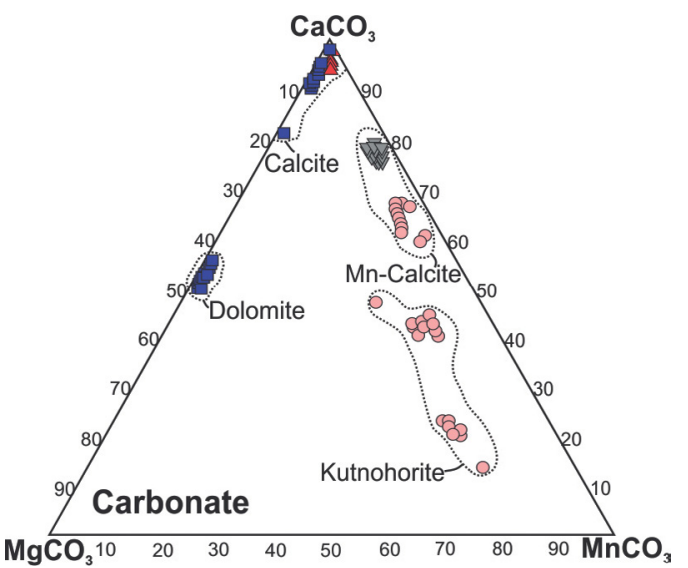

$\mathrm{C}$

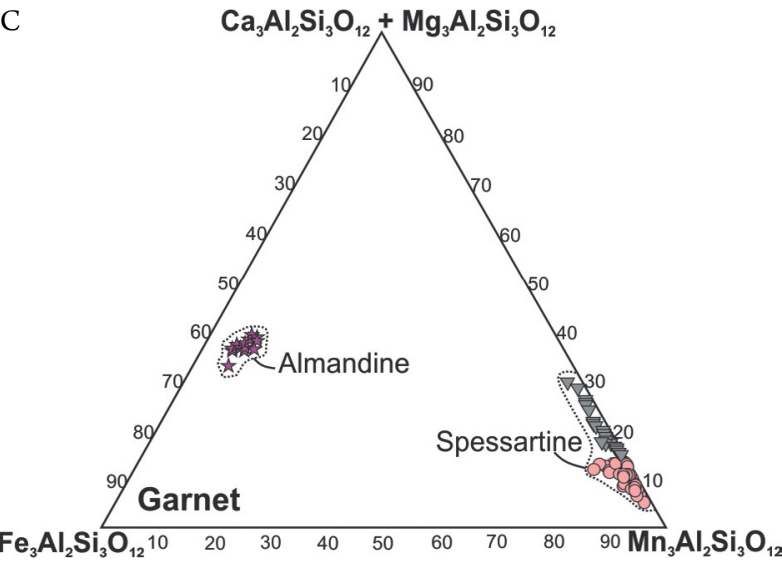

$\mathrm{E}$

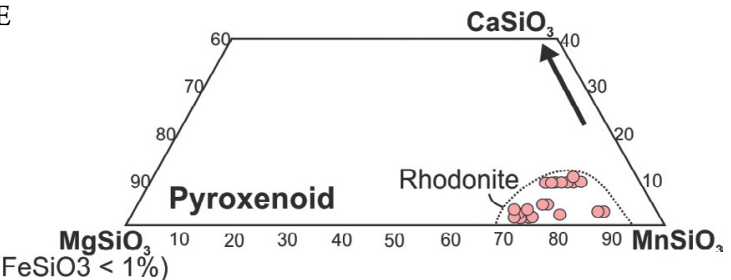

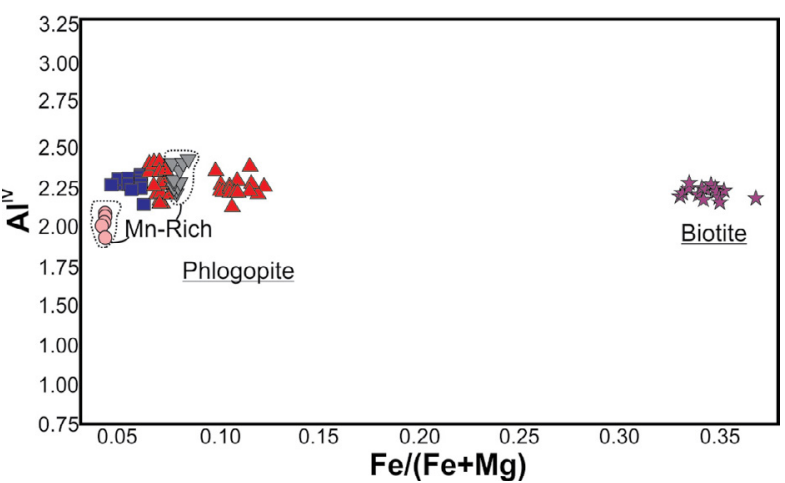

Figure 8. Binary diagram (based on Deer et al. 1992) showing mica composition of Buritirama Formation.
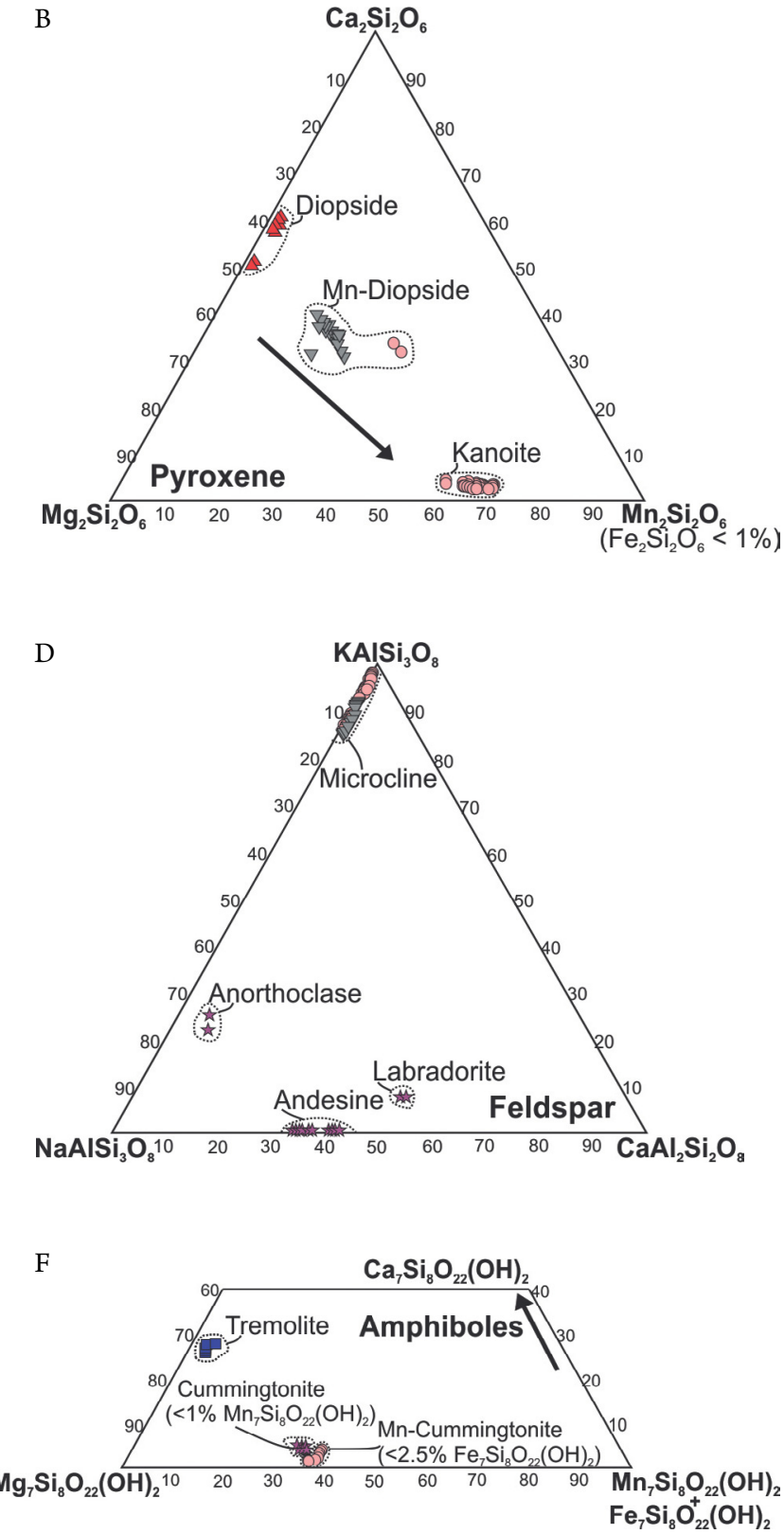

Impure Marble $O$ Manganesiferous Marble $\triangle$ Carbonate-Silicate Rocks $\nabla$ Mn-Carbonate-Silicate Rocks $\succsim$ Silicate Rocks Figure 7. Ternary diagrams showing the mineral composition of: (A) carbonates (Goldsmith \& Graf 1960); (B) pyroxenes (Morimoto 1988); (C) garnets (modified from Klein \& Duthow 2007); (D) feldspars (Deer et al. 1992); (E) piroxenoid (Peacor et al. 1978); (F) amphiboles (Klein \& Duthow 2007) for different lithologies of Buritirama Formation. 
lineation $\left(\mathrm{L}_{\mathrm{s}}\right)$, formed by quartz and mica, occurs on the S2 plane. $\mathrm{L}_{\mathrm{s}}$ dips chiefly to NE with parallel/sub-parallel trend to F2 hinge (Fig. 9E). Sinistral shear folds related to steep $S 2$ are present in the basal boundary of the BF. Narrow branches of ductile shear zones distinguished by mylonitic rocks ( $\mathrm{S}-\mathrm{C}$ foliation and mantled porphyroclasts are easily recognizable; Fig. 10A) cross the ridge parallel to S2, overprinting F2 folds and recording a tectonic transport towards SW. The imbricated thrusts that build the ridge are broken apart in minor segments by transfer shear zones (Fig. 10B). Gentle upright folds (F3) with horizontal hinges plunging at a low angle to NW and SE (Figs. 11A and 11B) represent the last expression of the D1 phase. The superimposed F2 and F3 folds constitute two types of interference folds, which depend on the interception angle between the hinges. When F2 and F3 hinges are parallel, Type 3 (Ramsay \& Huber 1987) interference pattern forms (Fig. 11C). However, the rotation of F2-hinges detected in some areas of the $\mathrm{BF}$ causes interception of F3-hinges at a high angle, constituting a Type 2 (mushroom; Ramsay \& Huber 1987) pattern (Fig. 11D). Sheath folds are also present, locally, within the shear zones;

- Phase D2: it is characterized by brittle reverse and backthrust faults verging to SW and NE, respectively. Reverse surfaces occur rather along the lithological transitions or oblique to them and dips ca. 40 (Fig. 12A). Back-thrusting give rise to fault-propagation folds gathered in the $\mathrm{F} 4$ pattern. F4 consists of open to close folds with hinge plunging at low angles to NW (Figs. 12B and 12C). It is coaxial to the F3-folds pattern;
- Phase D3: it represents an essentially brittle and extensional regime characterized by conjugated normal faults that, despite significant angular variation, can be represented by the two modal maximum at $141 / 87$ and 254/87 (Figs. 13A and 13B).
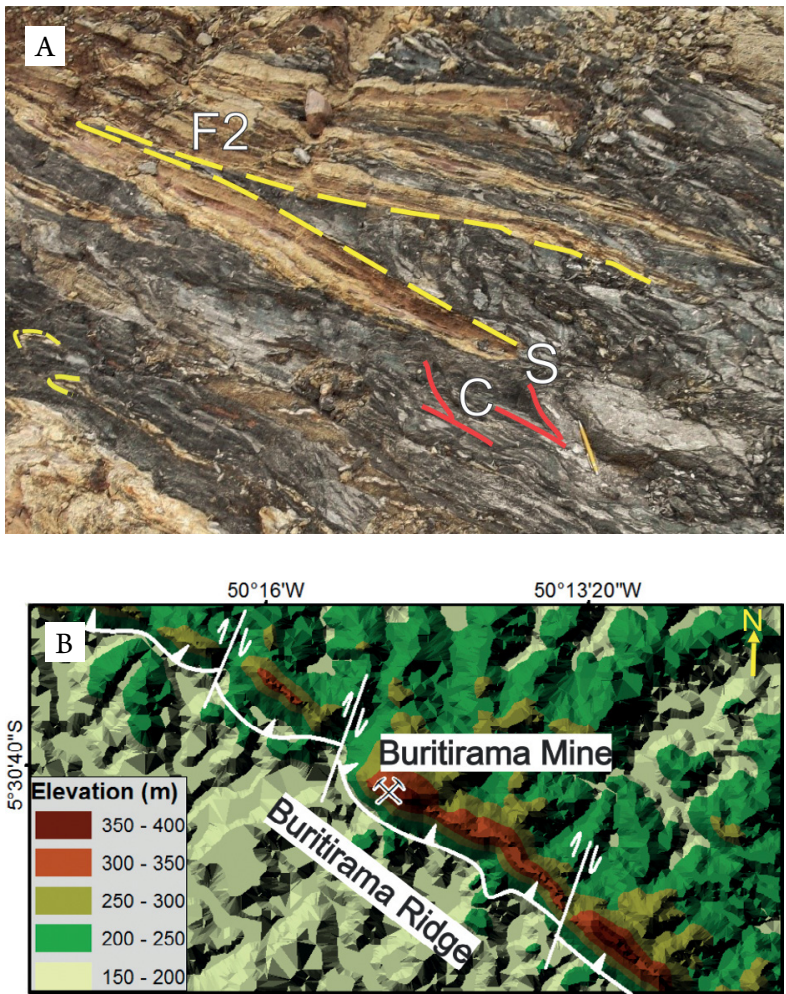

Figure 10. Shear zones related to phase D1. (A) F2-fold pattern transposed by ductile reverse shear zone; (B) digital elevation model of the Buritirama ridge (NW-SE) split by transfer faults (NE-SW) in different sections.
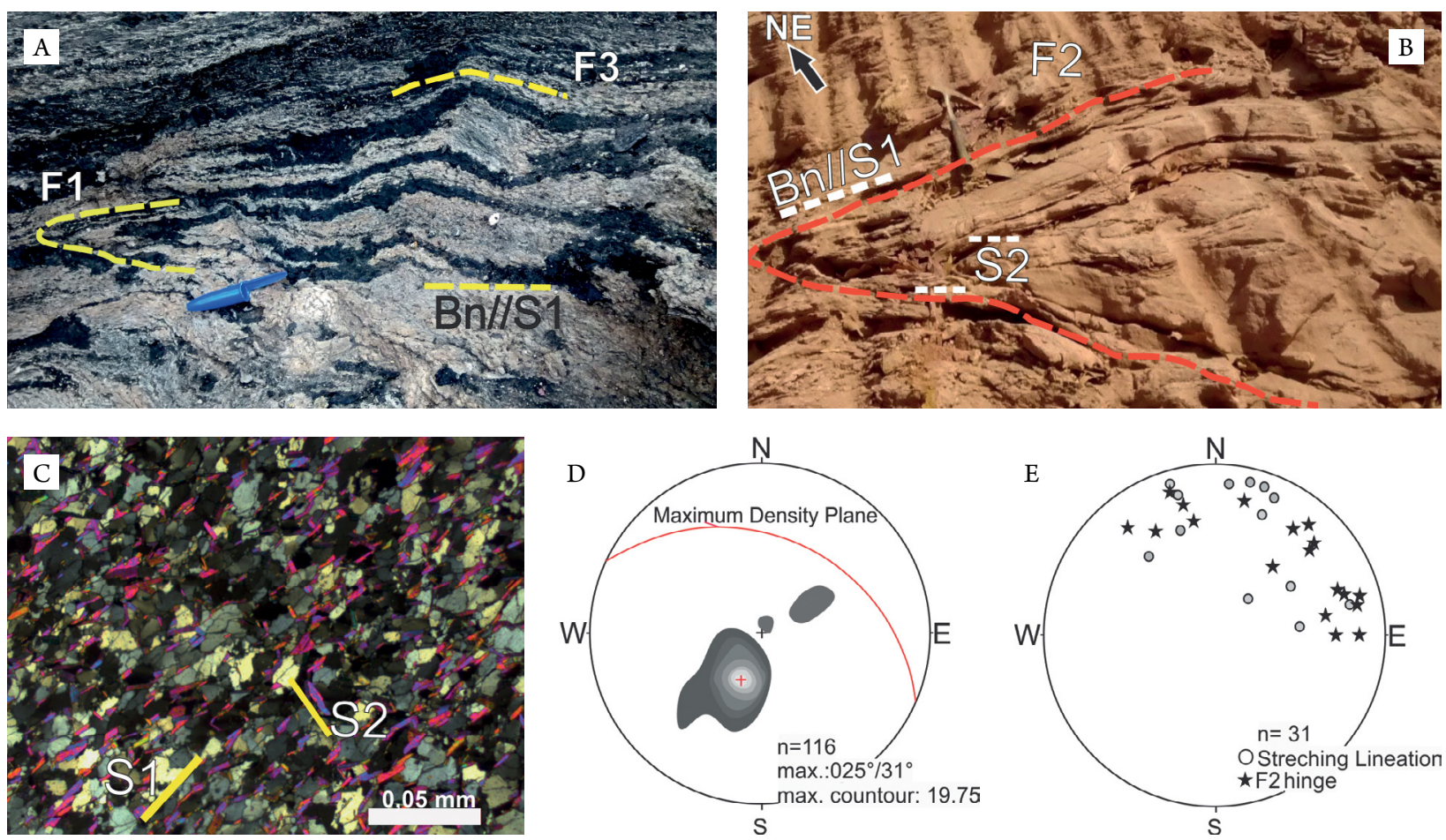

Figure 9. Structural features of phase D1. (A) Intrafolial fold (F1) and Bn parallel to S1; (B) isoclinal folds (F2) with axial-plane foliation (S2); (C) photomicrograph exhibiting the relationship between S1 and S2 (marked by muscovite) in the hinge-zone of F2 fold-pattern; (D) equal area lower hemisphere projection showing S1//S2//Bn distribution; (E) equal area lower hemisphere projection showing distribution of stretching lineation and F2-hinge. 

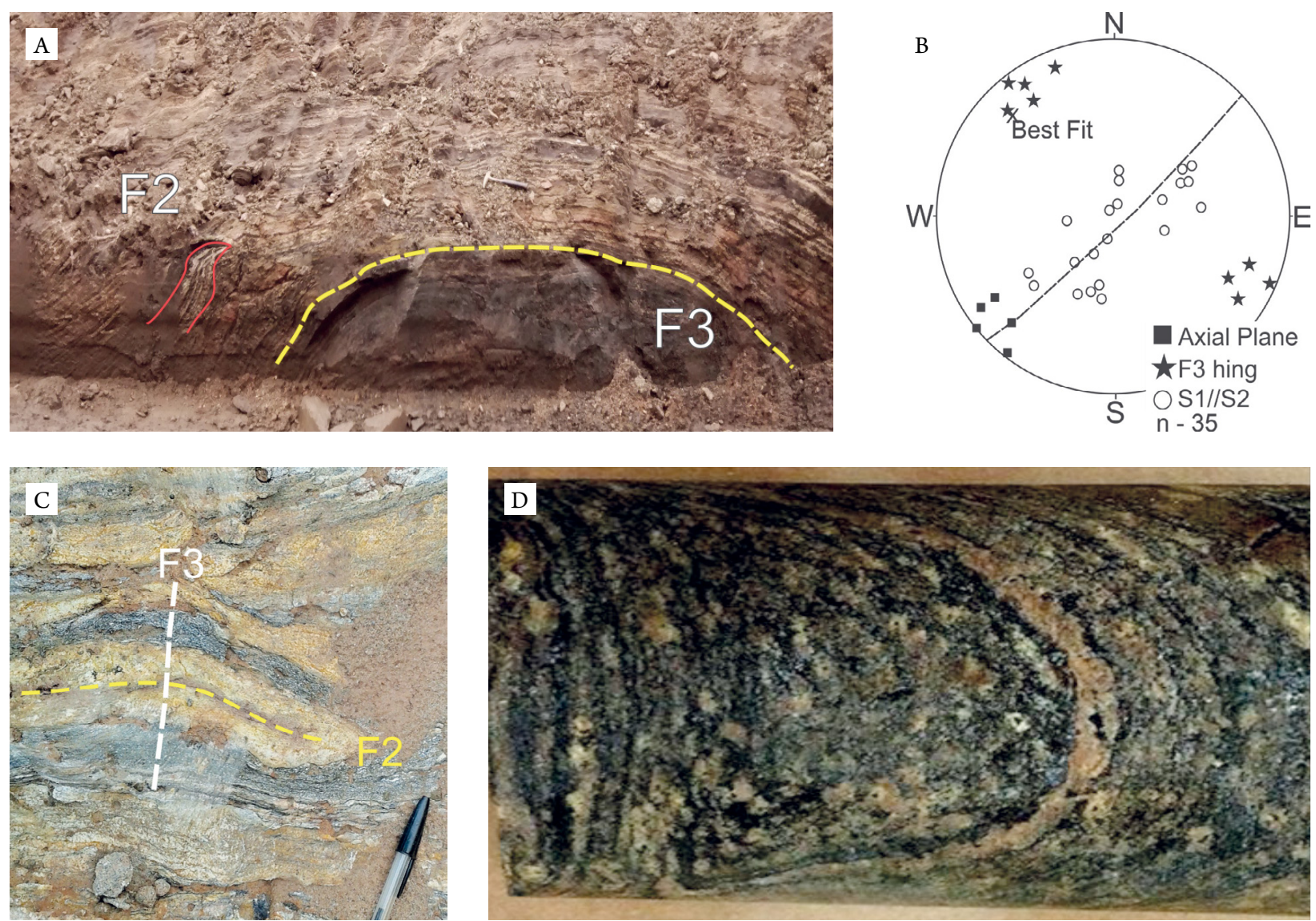

Figure 11. Structural features of phase D1. (A) Gently upright F3 fold; (B) equal area lower hemisphere projection showing the main structures of F3 pattern; (C) superimposed F2 and F3 folds giving rise to type 3; (D) type 2 (mushroom) interference patterns (borehole diameter of $9.8 \mathrm{~cm})$.
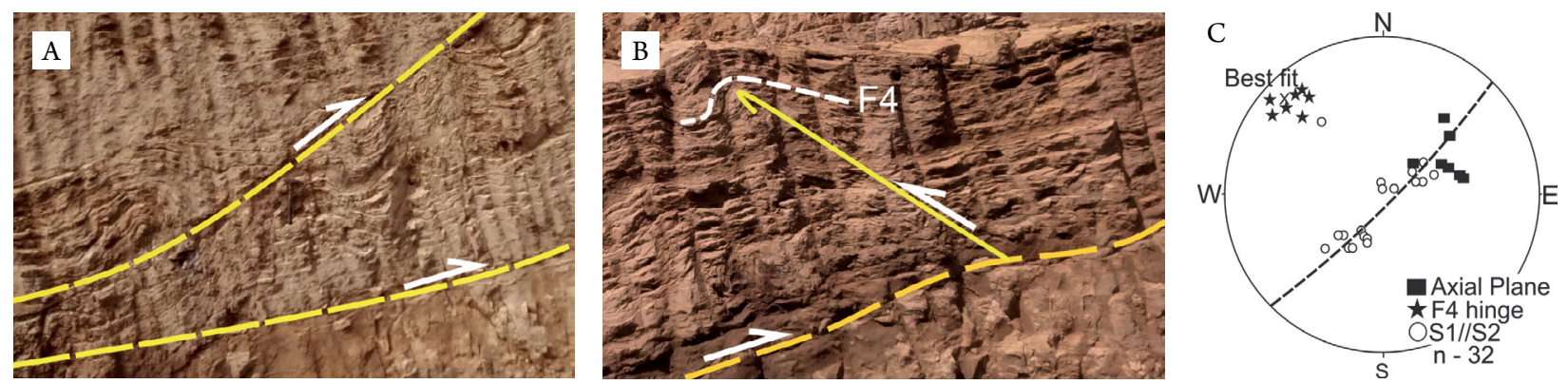

Figure 12. Structural features of phase D2. (A) Reverse faults; (B) back-thrusting associated to F4 folds pattern; (C) equal area lower hemisphere projection showing the main structures of $\mathrm{F} 4$ pattern.
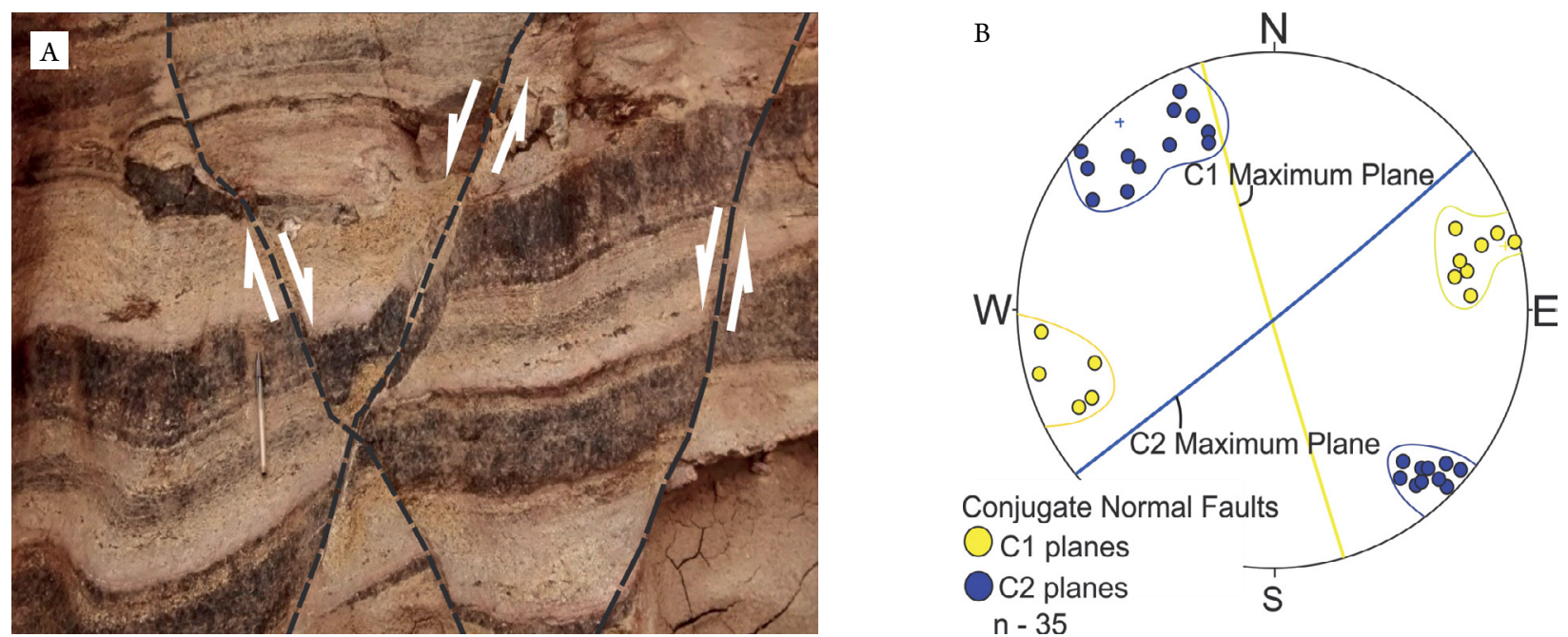

Figure 13. Structural features of phase D3. (A) Normal faults impressed in manganesiferous saprolite; (B) equal area lower hemisphere projection showing the normal conjugate planes $\mathrm{C} 1$ and $\mathrm{C} 2$. 


\section{DISCUSSION}

\section{Mineral paragenesis, metamorphic reactions and protoliths of metamorphic rocks}

The mineral paragenesis of the $\mathrm{BF}$ are compiled in the Table 1. Carbonates textures and chemistry data from impure marbles, manganesiferous marbles, calc-silicate rocks and carbonate-silicate rocks suggest that these minerals were consumed by metamorphic reactions, producing silicate phases. Diopside and $\mathrm{Mn}$-diopside were probably formed by reactions involving dolomite and Mn-calcite, respectively (Reactions 1 and 2). Rhodonite is restricted to kutnohorite-bearing rocks, and the expressive $\mathrm{Mg}$ content in both minerals corroborates its genetic relation (Reaction 3). Kanoite is for the first time reported in Brazil and it is normally recognized in Mn deposits (Kobayashi 1977, Dasgupta et al. 1990). Diopside, Mn-diopside and kanoite compositions point to solid solution reactions (Brown et al. 1980) as it is also the case for calcite, $\mathrm{Mn}$-calcite and kutnohorite. The very low abundance of quartz and its occurrence as inclusions or relict crystals indicate it was probably consumed in the mentioned reactions.

- dolomite + quartz $=$ diopside + carbon dioxide $($ Reaction 1$)$;

- Mg-kutnohorite + quartz $=$ Mn-diopside + carbon dioxide (Reaction 2);

- kutnohorite + quartz $=$ rhodonite + carbon dioxide (Reaction 3).

Microcline and phlogopite have also a large distribution in BF lithotypes. In some samples, the occurrence of microcline exclusively as inclusions in pyroxene coupled with phlogopite overgrowth texture indicates a reaction probably involving dolomite (Reaction 4). Despite of the previous reactions, marked essentially by decarbonatization process, water is required for phlogopite formation (Kretz \& Garrett 1980, Sanford 1980) and could derive from dehydration reactions (metamorphic grade increasing) or external sources.

- dolomite + microcline + water $=$ phlogopite + calcite + carbon dioxide (Reaction 4)

A low-amphibolite metamorphic grade has been previously indicated for the BF (Peters et al. 1977, Valarelli et al. 1978), which is also pointed out by diopside, Mn-diopside, kanoite and calcite, Mn-calcite and kutnohorite solid solutions (Brown et al. 1980, Capitani \& Peters 1981). The Paleoproterozoic metamorphic age $(2.1 \mathrm{Ga}$; Transamazonic event; Costa et al. 2016) recorded in the basement nearby the Buritirama ridge can also be tentatively attributed to the metamorphism of the BF (Macambira et al. 2009).

The mineral paragenesis and metamorphic reactions described for carbonate-silicate rocks and impure marbles indicated that both group of rocks represent metamorphic product of marls and/or silt-argillaceous limestones, probably composed mainly of carbonates (calcite, Mn-calcite, dolomite and kutnohorite), quartz, K-feldspar and clay-minerals (Roy 1972, Ferry 1976, 1983, Sanford 1980, Yardley 1989, Bucher \& Grapes 2011).

\section{Structural evolution}

The structural assemblage of the BF records an essentially Transamazonic-age compressional event (Gomes et al. 1975, Costa et al. 2016) responsible for mass transport from NE to SW, that is summarized in the following phases (Fig. 14):

$\mathrm{D} 1$ is the earlier phase and marked by a low-angle (ca. $\left.30^{\circ}\right)$ ductile simple shear deformation related to S1, S2 and Bn formation and for the development of fold generations F1, F2 and F3. Bn is mainly controlled by protolith compositional variation as suggested by thin $(<1 \mathrm{~cm})$ metamorphic banding, but can be also related to porphyroblast deformation. D1 gave rise to ductile reverse shear zones verging to SW and responsible for the thrust stacking of the BF. A dextral strike-slip shear zone impressed in the Xingu Complex (basement) hampered the SW-verging mass transport, creating a sharp foliation (dip deflection) at the BF basal contact and contributing to back-thrust development.

D2 represents the beginning of the brittle tectonic regime that is characterized by reverse and back-thrust faults. Fault-propagation folds (F4) verging to NE and related to back-thrust faults formed at this time;

The final stage, D3, comes up after the contractional forces have ceased and is recognized by the presence of conjugate normal faults. NE-SW diabase dykes cutting the ridge indicate that transfer faults were probably later reactivated as normal faults.

\section{Depositional setting}

The lithotypes of the BF are metamorphic rocks with no preserved sedimentary features that could be used to infer a specific depositional environment. However, marls and limestones are commonly related to a marine platformal system which is also suggested for the BF by:

- the basal orthoquartzite, often connected to transitional environments;

- the presence of significant grades of Ba registered by barite (impure marbles) and Ba-rich feldspar;

Table 1. Mineral paragenesis of Buritirama Formation lithotypes.

\begin{tabular}{|c|c|c|c|c|c|}
\hline Minerals/ Rock Groups & CBS & MCBS & IM & MM & SR \\
\hline \multicolumn{6}{|l|}{ Calcite } \\
\hline \multicolumn{6}{|l|}{ Dolomite } \\
\hline \multicolumn{6}{|l|}{ Mn-Calcite } \\
\hline \multicolumn{6}{|l|}{ Kutnohorite } \\
\hline \multicolumn{6}{|l|}{ Rhodonite } \\
\hline \multicolumn{6}{|l|}{ Diopside } \\
\hline \multicolumn{6}{|l|}{ Mn-Diopside } \\
\hline \multicolumn{6}{|l|}{ Kanoite } \\
\hline \multicolumn{6}{|l|}{ Cummingtonite } \\
\hline \multicolumn{6}{|l|}{ Mn-Phlogopite } \\
\hline \multicolumn{6}{|l|}{ Phlogopite } \\
\hline \multicolumn{6}{|l|}{ Biotite } \\
\hline \multicolumn{6}{|l|}{ Microcline } \\
\hline \multicolumn{6}{|l|}{ Almandine } \\
\hline \multicolumn{6}{|l|}{ Spessartine } \\
\hline \multicolumn{6}{|l|}{ Quartz } \\
\hline Muscovite & & & & & \\
\hline
\end{tabular}

CBS: carbonate-silicate rock; MCBS: manganesiferous carbonate-silicate rock; IM: impure marble; MM: manganesiferous marble; SR: silicate rock. 
- high $\mathrm{Mn} / \mathrm{Fe}$ fractionation recorded by the substitution of Fe by $\mathrm{Mn}$ in mineral structure and the very low abundance of iron oxide (Force \& Cannon 1988, Maynard 2010);

- the similarities between Buritirama mineralization and hostrocks associated with platformal-interpreted manganesiferous deposits such as the Sausar and Sandur groups (India) and Franceville Group (Gabon) (Roy 2006);

- the most accepted depositional model for manganesiferous carbonates formation assume a platformal sub-oxic/anoxic environment (Force \& Cannon 1988, Okita et al. 1988, Maynard 2010).

\section{Tectonic considerations}

The new data presented in this paper suggests that the $\mathrm{BF}$ at the homonymous ridge is part of a compressional orogenic system develop during the Transamazonic cycle ( 2.1 Ga; Macambira et al. 2007, Cordani et al. 1984, Gomes et al. 1975, Costa et al. 2016) in response to amalgamation between the Carajás and Bacajá blocks (Macambira et al. 2009). Tectonic features of this orogenic event are strongly impressed in the $\mathrm{BF}$ and have also been documented in the inner part of the Carajás domain (Pereira 2009, Tavares 2015), breaking the paradigm of restricted Archean deformation for this area (Machado et al. 1991, Pinheiro \& Holdsworth 2000). Detrital zircons dated in a paragneiss, located about $25 \mathrm{~km}$ north of the Buritirama ridge, suggest a provenance likely derived from the Carajás domain and corroborate the presence of an ArcheanPaleoproterozoic basin for this area (Macambira et al. 2007). A probable foreland basin (Caninana Formation) has been also related to the later stages of this collisional system (Pereira 2009). Considering the BF as formed in a platformal setting at the border of the Carajás domain, two different tectonic frameworks can be proposed: the BF represents an ensialic platform related to an aborted rift, or the BF represents a continental platform connected to an oceanic basin (Fig. 15). Geochronological and isotopic studies are being conducted in order to clarify this issue.

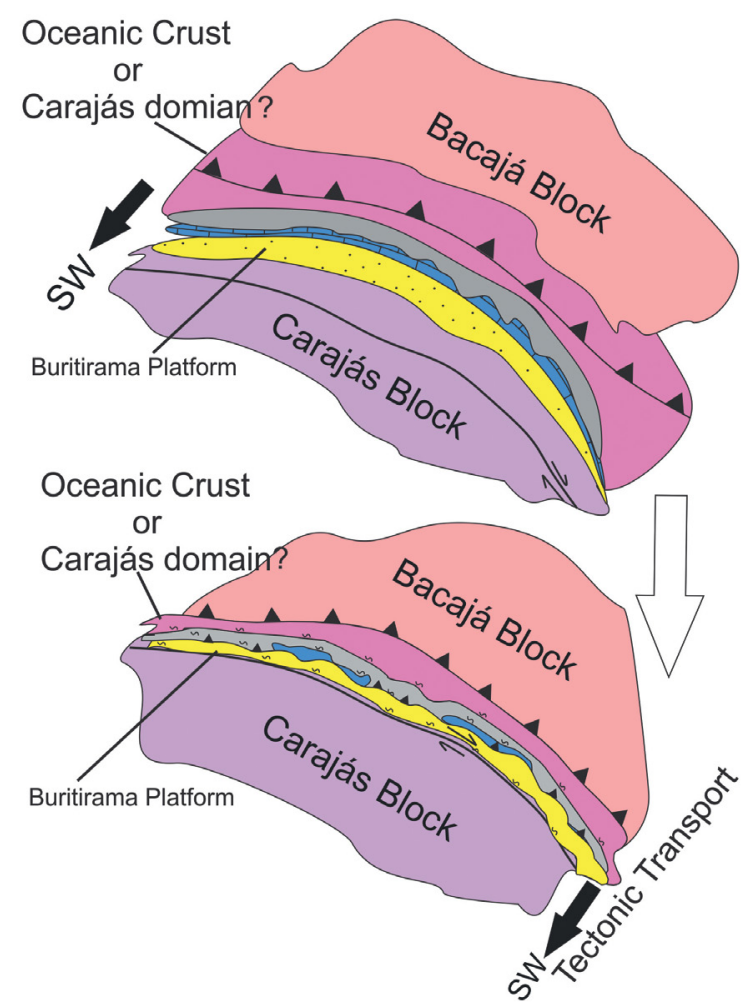

Figure 15. Schematic tectonic models for evolution of the Buritirama Formation in the border zone between the Bacaja and Carajás blocks. In this model, the Buritirama Formation represents an Archean / Paleoproterozoic continental platform of the northern Carajás Block connected to an oceanic basin, which was closed during the Paleoproterozoic Transamazonic Orogeny, when the Carajás and Bacajá blocks collided and amalgamated, causing metamorphism and thrusting of the Buritirama Formation over the Carajás block (lower plate) to the southwest.


Phase 1 (compressional) - Progressive ductile deformation

\section{Phase 2 (compressional) - thrust and back-thrust faults}

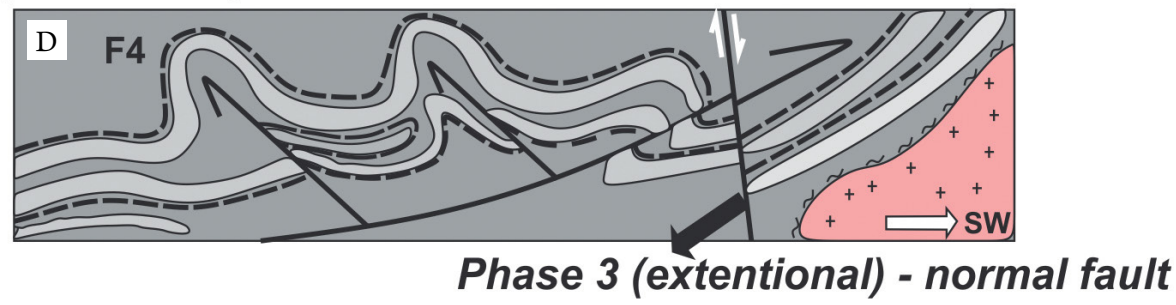

Figure 14. Structural evolution of the Buritirama Formation. Progressive ductile deformation: (A) starting with intrafolial folds associated to $\mathrm{Bn} / / \mathrm{S} 0$ transposition and S1; (B) reclined fold F2 with the S2 axial plane verging; (C) vertical upright F3 fold; (D) brittle regime marked by a reverse fault, back-thrust faults and F4 verging to NE. 


\section{CONCLUSIONS}

The BF along the homonymous ridge consists of four imbricated reverse shear zones that individualize three main metamorphic units: LU, mainly siliciclastic and carbonate-silicate rocks; IU, mainly carbonate-silicate rocks and manganesiferous marbles; and UU, mainly carbonate-silicate rocks. The supergene $\mathrm{Mn}$-deposit is formed by weathering of kutnohorite-rich marble and restricted to the IU. The BF basement is composed of orthogneiss of the Xingu Complex and the Buritirama metagranite. A dextral strike-slip shear zone impressed in the Xingu Complex bounds the basal contact, while the uppermost contact is defined by a quartz-iron rich hidrothermalized rock.

The BF lithotypes record an abundant presence of carbonate minerals (calcite, dolomite and kutnohorite) that, combined with quartz, clay-minerals and k-feldspar, were probably a major constituent of marls and impure limestones protoliths. In addition, the minerals paragenesis recognized in the $\mathrm{BF}$ have been interpreted as a metamorphic product of such sedimentary rocks, normally related to a platformal environment.

The BF is interpreted as part of a platformal depositional system positioned at the border of the Carajás domain, which was probably inverted, deformed and metamorphosed during the Transamazonian event $(\sim 2.1 \mathrm{Ga})$, in a deformation belt related to the amalgamation between the Carajás and Bacajá blocks.

\section{ACKNOWLEDGMENTS}

This work was greatly facilitated by Buritirama Mineração, that allowed the access to borehole cores and mapping areas. The authors acknowledge João Araújo, Jorge Baptista and Maurício Soares, all members of Buritirama Mineração, and Felipe Tavares, from Brazilian Geological Survey (CPRM). Analytical facilities of Centro de Pesquisa Manoel Teixeira da Costa (CPTMC), Geoscience Institute of Universidade Federal de Minas Gerais (IGC-UFMG), and of Laboratory of Microscopy and Microanalyses (LMIc), integrated to the Universidade Federal de Ouro Preto, provided additional support for this research. Fabrício Caxito and Glaucia Queiroga are fellow of the Brazilian Council for Scientific and Technological Development (CNPq) and acknowledges for the support received. The original manuscript was greatly improved after constructive and helpful comments and suggestions by two anonymous reviewers.

\section{ARTICLE INFORMATION}

Manuscript ID: 20180106. Received on: 09/25/2018. Approved on: 02/21/2019.

S. S. S. was responsible for writing the whole paper and the fieldwork. F. A. C. helped during the manuscript confection and was responsible for the first review. G. N. Q. and M. P. C. helped with the mineral chemistry analyses.

Competing interests: The authors declare no competing interests.

\section{REFERENCES}

Almeida F.F., Brito Neves B.B., Carneiro C.D.R. 2000. The origin and evolution of the South American Platform. Earth Science Review, 50:77-111.

Almeida F.F., Hasui Y., Brito Neves B.B. 1976. The Upper Precambrian of South America. Boletim IG, 7:45-80.

Almeida F.F., Hasui Y., Brito Neves B.B., Fuck R.A. 1981. Brazilian structural provinces: an introduction. Earth Science Review, 17 (1-2):1-29.

Alvarenga C.J.S., Moura C.A.V., Gorayeb P.S., Abreu F.A.M. 2000. Paraguai and Araguaia belts. In: Cordani U.G., Milani E.J., Thomaz Filho A., Campos D.A. (Ed.), Tectonic evolution of South America. Rio de Janeiro: Beca, p. 183-193.

Anderson W.L., Dyer R.C., Tores D.D. 1974. Ocorrências de manganês na bacia do Rio Itacaiúnas, centro-leste do Estado do Pará. In: Congresso Brasileiro de Geologia, 26., Porto Alegre. Proceedings... p. $149-164$

Andrade M.S., Nakashima J., Podestá P.R. 1986. Depósito de manganês da Serra de Buritirama, Pará. In: Schobbenhaus C., Coelho C.E.S. (Eds.). Principais Depósitos Minerais do Brasil. Brasil: DNPN/Companhia Vale do Rio Doce, v. II, p. 153-166.

Araújo O.J.B., Maia R.G.N. 1991. Programa Levantamentos Geológicos Básicos do Brasil (PLGB), Serra dos Carajás: folha SB.22-Z-A, Estado do Pará. Escala 1:250.000. Texto explicativo. Brasília: DNPM/CPRM, $164 \mathrm{p}$.

Araújo O.J.B., Maia R.G.N.M., João X.S.J., Costa J.B.S. 1988. A Megaestruturação Arqueana da Folha Serra dos Carajás. In: Congresso Latino Americano de Geologia, 7., Belém. Anais... v. 1. p. 324-338.
Barbosa J.P.O. 2004. Geologia Estrutural, Geoquímica, Petrografia e Geocronologia de Granitóides da Região do Igarapé Gelado, Norte da Província Mineral de Carajás. MS Dissertation, Centro de Geociências, Universidade Federal do Pará, Belém, 112 p.

Beisiegel V.R., Bernardelli A.L., Drummond N.F., Ruff A.W., Tremaine J.W. 1973. Geologia e Recursos Naturais da Serra dos Carajás. Revista Brasileira de Geociências, 3(4):215-242.

Bello R.M.S. 1978. Condições de Metamorfismo de Buritirama, Pará e Serra do Navio, Amapá. MS Dissertation, Instituto de Geociências, Universidade de São Paulo, São Paulo, 154 p.

Besser M.L. 2012. Origem e Evolução das Rochas Paleoproterozoicas da Área Rio Bacajá, Pará, Brasil. MS Dissertation, Setor de Geociências, Universidade Federal do Paraná, Curitiba, 136 p.

Brito Neves B.B., Cordani U.G. 1991. Tectonic evolution of South America during Late Proterozoic. Precambrian Research, 53(1-2):2340. https://doi.org/10.1016/0301-9268(91)90004-T

Brown P.E., Essene E.J., Peacor D.R. 1980. Phase Relations Inferred from Field Data for Mn Pyroxenes and Pyroxenoids. Contributions to Mineralogy and Petrology, 74(4):417-425. https://doi.org/10.1007/ BF00518121

Bucher K., Grapes R. 2011. Petrogenesis of Metamorphic Rocks. Berlin: Springer-Verlag, $428 \mathrm{p}$.

Capitani C., Peters T. 1981. The Solvus in the System $\mathrm{MnCO}_{3}-\mathrm{CaCO}_{3}$. Contributions to Mineralogy and Petrology, 76(4):394-400. https://doi. org/10.1007/BF00371481 
Cordani U.G., Tassinari C.C.G., Kawashita K. 1984. A Serra dos Carajás como região limítrofe entre províncias tectônicas. Ciências da Terra, 9:6-11.

Cordani U.G., Tassinari C.C.G., Teixeira W., Basei M.A.S. 2000. Crustal evolution of the South América Platform. In: Cordani U.G., Milani E.J., Thomaz Filho A., Campos D.A. (eds.). Tectonic Evolution of South America. Rio de Janeiro: Beca, p. 19-40.

Costa J.B.S., Hasui Y. 1997. O Pré-Cambriano da Região Amazônica no Brasil. In: Simpósio Nacional de Estudos Tectônicos, Pirenópolis. Proceedings... p. 39-41.

Costa U.A.P., Paula R.R., Silva D.P.B., Barbosa J.P.O., Silva C.M.G., Tavares F.M., Oliveira J.K.M., Justo A.P. 2016. Programa Geologia do Brasil (PGB). Mapa de Integração Geológico-Geofísica da ARIM Carajás. Estado do Pará. Escala 1:250.000. Belém: CPRM.

Dall'Agnol R., Oliveira D.C., Lamarão C.N. 2013. Magmatismo granitoide arqueano e evolução geológica do Subdomínio de Transição da Província Carajás, sudeste do Cráton Amazônico, Brasil. Boletim do Museu Paraense Emílio Goeldi. Ciências Naturais, 8(3):251-256.

Dall'Agnol R., Teixeira P.N., Ramo O.T., Moura C.A.V., Macambira M.J.B., Oliveira D.C. 2005. Petrogenesis of the Paleoproterozoic rapakivi A-type granites of the Archean Carajás metallogenic province, Brazil. Lithos, 80(1):101-129. http://dx.doi.org/10.1016/j. lithos.2004.03.058

Dasgupta S., Banerjee H., Fukuoka M., Bhattacharya P.K., Roy S. 1990. Petrogenesis of Metamorphosed Manganese Deposits and the Nature of Precursor Sediments. Ore Geology Review, 5(4):359-384. https:// doi.org/10.1016/0169-1368(90)90039-P

Deer W.A., Howie R.A., Zussman J.K. 1992. An introduction to the rock-forming minerals. England: Longman Group, 696 p.

Delinardo M.A.S. 2014. Metatexitos e diatexitos do Complexo Xingu na região de Canaã dos Carajás: implicações para a evolução mesoarqueana do Domínio Carajás. MS Dissertation, Instituto de Geociências, Universidade Estadual de Campinas, Campinas, 119 p.

Faraco M.T.L., Vale A.G., Santos J.O., Luzardo R., Ferreira A.L., Oliveira M. Marinho P.A.C. 2005. Levantamento geológico da região ao norte da Província Carajás: Notícias Preliminares. In: Simpósio de Geologia da Amazônia, Manaus. Short-Paper... p. 131-136.

Ferreira Filho C.F., Cançado F., Correa C., Macambira E.M.B., Siepierski L., Junqueira-Brod T.C. 2007. Mineralizações estratiformes de EGP-Ni associadas a complexos acamadados em Carajás: os exemplos de Luanga e Serra da Onça. In: Rosa-Costa L.T., Klein E.L., Viglio E.P. (Eds.). Contribuições à Geologia da Amazônia. Belém: Publitec, p. 1-14.

Ferry J.M. 1976. Metamorphism of Calcareous Sediments in the Waterville-Vassalboro Area, South-Central Maine: Mineral Reactions and Graphical Analysis. American Journal of Science, 276:841-882. https://doi.org/10.2475/ajs.276.7.841

Ferry J.M. 1983. Regional metamorphism of the Vassalboro Formation, south-central Maine, USA: a case study of the role of fluid in metamorphic petrogenesis. Journal of Geological Society, 140:551-576. https://doi.org/10.1144/gsjgs.140.4.0551

Force E.R., Cannon W.F. 1988. Depositional Model for Shallow-Marine Manganese Deposits around Black Shale Basins. Economic Geology, 83(1):93-117. http://dx.doi.org/10.2113/gsecongeo.83.1.93

Gibbs A.K., Wirth K.R., Hirata W.K., Olszewski Jr. W.J. 1986. Age and composition of the Grão Pará Group volcanics, Serra dos Carajás. Revista Brasileira de Geociências, 16(2):201-211.

Goldsmith J.R., Graf D.L. 1960. Subsolidus Relations in the System CaCO3-MgCO3-MnCO3. Journal of Geology, 68(3):324-335. https:// doi.org/10.1086/626662

Gomes C.B., Cordani U.G., Basei M.A.S. 1975. Radiometric ages from the Serra dos Carajás area, Northern Brazil. Geological Society of America Bulletin, 86(7):939-942. https://doi. org/10.1130/0016-7606(1975)86\%3C939:RAFTSD\%3E2.0.CO;2

Grainger C.J., Groves D.I., Tallarico F.H.B., Fletcher I.R. 2008. Metallogenesis of the Carajás Mineral Province, Southern Amazon Craton, Brazil: Varying styles of Archean through Paleoproterozoic to Neoproterozoic base- and precious-metal mineralisation. Ore Geology Reviews, 33(3-4):451-489. http://dx.doi.org/10.1016/j. oregeorev.2006.10.010

Hasui Y., Almeida F.F.M. 1985. The Central Brazil Shield Reviewed. Episodes, 8(1):29-37.

Herz N., Hasui Y., Costa J.B.S., Matta M.A.S. 1989. The Araguaia Fold Belt, Brazil: a reactived Brasiliano/Pan-African Cycle (550Ma) geosuture. Precambrian Research, 42(3-4):371-386. https://doi. org/10.1016/0301-9268(89)90020-X

Klein C., Duthow B. 2007. Manual of Mineral Science. Michigan: Willey, $716 \mathrm{p}$.

Kobayashi H. 1977. Kanoite (Mn2+, Mg)2 [Si2O6], a New Clinopyroxene in the Metamorphic Rock From Tatehira, Oshima Peninsula, Hokkaido, Japan. Journal of Geological Society of Japan, 83(8):537-542. https://doi.org/10.5575/geosoc.83.537

Kretz R., Garrett D. 1980. Occurence, Mineral Chemistry, and Metamorphism of Precambrian Carbonate Rocks in a Portion of Grenille Province. Journal of Petrology, 21(3):573-620. https://doi. org/10.1093/petrology/21.3.573

Macambira J.B. 2003. O ambiente deposicional da Formação Carajás e uma proposta de modelo evolutivo para a Bacia Grão Pará. $\mathrm{PhD}$ Thesis, Universidade Estadual de Campinas, Campinas, 217 p.

Macambira J.B., Macambira M.J.B., Scheller T., Gomes A.C.B. 1996. Geocronologia $\mathrm{Pb} / \mathrm{Pb}$ e tipologia de zircões de rochas vulcânicas da Formação Carajás - Pará: Indicador da idade dos BIFs. In: Congresso Brasileiro de Geologia, 39., Salvador. Proceedings... v. 6, p. 516-518.

Macambira M.J.B., Pinheiro R.V.L., Armstrong R.A. 2007. A fronteira Arqueano-Paleoproterozóico no SE do Cráton Amazônico; abrupta no tempo, suave na tectônica? In: Simpósio de Geologia da Amazônia, 10. Proceedings... p. 105-108.

Macambira M.J.B., Vasquez M.L., Silva D.C.C., Galarza M.A., Barros C.E.M., Camelo J.F. 2009. Crustal growth of the central-eastern Paleoproterozoic domain, SW Amazonian craton: Juvenile accretion vs. reworking. Journal of South American Earth Sciences, 27:235-246. https://doi.org/10.1016/j.jsames.2009.02.001

Machado N., Lindenmayer D.H., Krogh T.E., Lindenmayer Z.G. 1991. $\mathrm{U}-\mathrm{Pb}$ geochronology of Archean magmatism and basement reactivation in the Carajás area, Amazon Shield, Brazil. Precambrian Research, 49(34):329-354. https://doi.org/10.1016/0301-9268(91)90040-H

Martins P.L.G. 2017. Petrologia e Geoquímica dos Basaltos da Formação Parauapebas: Implicações para o Ambiente Tectônico da Bacia Grão Pará, Província de Carajás. MS Dissertation, Instituto de Geociências, Universidade de Brasília, Brasília, 93 p.

Maynard J.B. 2010. The Chemistry of Manganese Ores through Time: A Signal of Increasing Diversity of Earth-Surface Environments. Economic Geology, 105(3):535-552. https://doi.org/10.2113/ gsecongeo.105.3.535

Meireles E.M., Hirata H.K., Amaral A.F., Medeiros Filho C.A., Gato W.C. 1984. Geologia das folhas Carajás e Rio Verde, Província Mineral dos Carajás, estado do Pará. In: Congresso Brasileiro de Geologia, 33., Rio de Janeiro. Proceedings... v. 5, p. 2164-2170.

Morimoto C.N. 1988. Nomenclature of Pyroxenes. American Mineralogist, 39(1):55-76. https://doi.org/10.1007/BF01226262

Moura C.A.V., Gaudette H. 1993. Evidence of Brasiliano/Panafrican deformation in the Araguaia Belt: Implication for Gondwana evolution. Revista Brasileira de Geociências, 23(2):117-123. https://doi. org/10.25249/0375-7536.1993232117123

Okita P.M., Maynard J.B., Spiker E.C., Force E.R. 1988. Isotopic evidence for organic matter oxidation by manganese reduction in the formation of stratiform manganese carbonate ore. Geochimica et Cosmochimica Acta, 52(11):2679-2685. https://doi.org/10.1016/0016-7037(88)90036-1

Oliveira J.R. 1994. Programa Levantamentos Geológicos Básicos do Brasil (PLGB). Carta Geológica, Carta Metalogenética, Escala 1:250.000, Folha SB.22-X-C, Serra Pelada, Estado do Pará. Brasil: DNPM/CPRM, 220 p. 
Peacor D.R., Essene E.J., Brown P.E., Winter G.A. 1978. The Crystal Chemistry and Petrogenesis of a magnesian rhodonite. American Mineralogist, 63(11-12):1137-1142.

Pereira R.M.P. 2009. Geologia da Região Sul da Serra Norte e Características do Minério de Ferro do Depósito N8, Província Mineral Carajás. MS Dissertation, Instituto de Geociências, Universidade Federal de Minas Gerais, Belo Horizonte, 131 p.

Peters T.J., Valarelli J.V., Coutinho J.M.V., Sommerauer J., Von Raumer J. 1977. The manganese deposits of Buritirama (Pará, Brazil). Schweizerische Mineralogische und Petrographische Mitteilungen, 57(3):313-327.

Pidgeon R.T., Macambira M.J.B., Lafon J.-M. 2000. Th-U-Pb isotopic systems and internal structures of complex zircons from an enderbite from the Pium Complex, Carajás Province, Brazil: evidence for the ages of granulite facies metamorphism and the protolith of the enderbite. Chemical Geology, 166(1):159-171. http://dx.doi.org/10.1016/ S0009-2541(99)00190-4

Pinheiro R.V.L. 1997. Reativation history of the Carajás and Cinzento strike-slip systems, Amazon, Brazil. PhD Thesis, University of Durham, Durham, $408 \mathrm{p}$

Pinheiro V.L., Holdsworth R.E. 2000. Evolução Tectonoestratigráfica dos Sistemas Transcorrentes Carajás e Cinzento, Cinturão Itacaiúnas, na Borda Leste do Cráton Amazônico, Pará. Revista Brasileira de Geociências, 30(4):597-606

Ramsay J.G., Huber M.I. 1987. The Techniques of Modern Structural Geology. London: Pergamon Press. v. 2.

Ricci P.S.F., Costa E.J.S., Faria C.A.S., Oliveira J.R. 2003. The reanalysed Carajás Block is interposed between the Bacajá (the crustal reworking "lost link" now being predicted) and Rio Maria Archean terranes-Guaporé Craton. In: Simpósio de Geologia da Amazônia, Manaus. Short Paper... p. 392-398.

Rio Doce Geologia e Mineração S.A. (DOCEGEO). 1988. Revisão litoestratigráfica da Província Mineral de Carajás - litoestratigrafia e principais depósitos minerais. In: Congresso Brasileiro de Geologia, 35., Belém. Anais... v. 35, p. 11-54.

Rosen O., Desmons J., Fettes D. 2007. Metacarbonate and related rocks. A systematic nomenclature for metamorphic rocks: 7 Metacarbonate and related rocks. A proposal on behalf of the IUGS Subcommission on the Systematics of Metamorphic Rocks. Recommendations. IUGS Subcommission on the Systematics of Metamorphic Rocks.

Roy S. 1972. Metamorphism of Sedimentary Manganese Deposits. Acta Mineralogica-Petrographica, 20(2):325-336.

Roy S. 2006. Sedimentary manganese metallogenesis in response to the evolution of the Earth system. Earth-Science Reviews, 77(4):273-305. http://dx.doi.org/10.1016/j.earscirev.2006.03.004

Sanford R.F. 1980. Textures and Mechanisms of Metamorphic Reactions in the Cockeysville Marble near Texas, Maryland. American Mineralogist, 65:654-669.

Santos J.O.S. 2003. Geotectônica dos Escudos da Guiana e Brasil Central. In: Bizzi L.A., Schobbenhaus C., Vidotti R.M., Gonçalves J.H. (eds.). Geologia, tectônica e recursos minerais do Brasil. Texto, mapas e SIG. Brasil: CPRM-Serviço Geológico do Brasil, p. 169-226.

Santos J.O.S., Hartmann L.A., Gaudette H.E., Groves D.I., McNaughton N.J., Fletcher I.R. 2000. A new understanding of the provinces of the Amazon Craton based on integration of field mapping and U-Pb and Sm-Nd geochronology. Gondwana Research, 3(4):453-488. http:// dx.doi.org/10.1016/S1342-937X(05)70755-3

Semblano F.R.D., Pereira N.C.S., Vasquez M.L., Macambira M.J.B. 2016. Novos dados geológicos e isotópicos para o Domínio Iriri-Xingu, Província Amazônia Central: implicações para a idade do Grupo Iriri.
Revista do Instituto de Geociências - USP, 16(3):19-38. https://doi. org/10.11606/issn.2316-9095.v16i3p19-38

Silva G.G., Lima J.J.C., Andrade A.R.F., Issler R.S., Guimarães G. 1974. Folha SB. 22 - Araguaia e parte da folha SC. 22 - Tocantins: geologia, geomorfologia, solos, vegetação e uso potencial da terra. Rio de Janeiro: DNPM, p. 143.

Siqueira J.B. 1996. Aspectos lito-estruturais e mineralizações do Depósito Salobo $3 A$ (Serra dos Carajás - PA). PhD Thesis, Universidade Federal do Pará, Belém, 157 p.

Suita M.T.F. 1988. Geologia da área Luanga com ênfase na petrologia do complexo básico-ultrabásico Luanga e depósitos de cromita associados, Pará. MS Dissertation, Instituto de Geociências, Universidade de Brasília, Brasília, 320 p.

Tallarico F.H.B., Figueiredo B.R., Groves D.I., Kositcin N., McNaughton N.J., Fletcher I.R., Rego J.L. 2005. Geology and SHRIMP U-Pb Geochronology of the Igarapé Bahia Deposit, Carajás Copper-Gold Belt, Brazil: An Archean (2.57 Ga) Example of Iron-Oxide Cu-Au-(UREE) Mineralization. Economic Geology, 100(1):7-28.

Tassinari C.C.G., Macambira M.J.B. 1999. Geochronological provinces of the Amazonian Craton. Episodes, 22(3):174-182.

Tassinari C.C.G., Macambira M.J.B. 2004. A evolução tectônica do Cráton Amazônico. In: Mantesso-Neto V., Bartorelli A., Carneiro C.D.R., Brito Neves B.B. (eds.). Geologia do continente Sul-americano: evolução da obra de Fernando Flávio Marques de Almeida. São Paulo: Beca, p. 471-485.

Tavares F.M. 2015. Evolução Geotectônica do Nordeste da Província Carajás. PhD Thesis, Universidade Federal do Rio de Janeiro, Rio de Janeiro, $115 \mathrm{p}$.

Tavares F.M., Trouw R.A.J., Silva C.M.G., Justo A.P., Oliveira J.K.M. 2018. The Multistage Tectonic Evolution of the Northeastern Carajás Province, Amazonian Craton, Brazil: Revealing Complex Structural Patterns. Journal of South American Earth Sciences, 88C:238-252. http://dx.doi.org/10.1016/j.jsames.2018.08.024

Trendall A.F., Basei M.A.S., De Laeter J.R., Nelson D.R. 1998. SHRIMP zircon U-Pb constraints on the age of the Carajás formation, Grão Pará Group, Amazon Craton. Journal of South American Earth Sciences, 11 (3):265-277. http://dx.doi.org/10.1016/S0895-9811(98)00015-7

Valarelli J.V., Coutinho J.M.V., Bello R.M.S. 1978. Metamorfismo de Buritirama, Pará. In: Congresso Brasileiro de Geologia, 30., Recife. Proceedings... v. 30, p. 1357-1363.

Vasquez M.L. 2006. Geocronologia em zircão, monazita e granada e isotópos de $\mathrm{Nd}$ das associações litológicas da porção oeste do domínio Bacajá: evolução crustal da porção meridional da província Maroniitacaiúnas - sudeste do cráton amazônico. $\mathrm{PhD}$ Thesis, Centro de Geociências, Universidade Federal do Pará, Belém, 212 p.

Vasquez M.L., Rosa-Costa L.T. 2008. Geologia e Recursos Minerais do Estado do Pará: Sistema de Informações Geográficas - SIG: texto explicativo dos mapas Geológico e Tectônico e de Recursos Minerais do Estado do Pará. Escala 1:1.000.000. Belém: CPRM, 328 p.

Whitney D.L., Evans B.W. 2010. Abbreviations for names of rock-forming minerals. American Mineralogist, 95(1):185-187. http://dx.doi. org/10.2138/am.2010.3371

Winter C.J. 1994. Geology and base-metal mineralization associated with Archaean iron formation in the Pojuca Corpo Quatro Deposit, Carajás, Brazil. $\mathrm{PhD}$ Thesis, University of Southampton, Southampton, $173 \mathrm{p}$.

Wirth K.R., Gibbs A.K., Olszewski Jr. W.J. 1986. U-Pb zircon ages of the Grão-Pará Group and Serra dos Carajás Granite. Revista Brasileira de Geociências, 16(2):195-200.

Yardley W.D.B. 1989. An Introduction to Metamorphic Rocks. United Kingdom: Harlow, 248 p. 